\title{
Review of Incoherent Broadband Cavity-Enhanced Absorption Spectroscopy (IBBCEAS) for Gas Sensing
}

\author{
Kaiyuan Zheng ${ }^{1}$, Chuantao Zheng ${ }^{1, *}$, Yu Zhang ${ }^{1}$, Yiding Wang ${ }^{1}$ and Frank K. Tittel ${ }^{2}$ (D) \\ 1 State Key Laboratory of Integrated Optoelectronics, College of Electronic Science and Engineering, \\ Jilin University, 2699 Qianjin Street, Changchun 130012, China; zhengkaiyuan1993@126.com (K.Z.); \\ yuzhang@jlu.edu.cn (Y.Z.); ydwang@jlu.edu.cn (Y.W.) \\ 2 Department of Electrical and Computer Engineering, Rice University, 6100 Main Street, \\ Houston, TX 77005, USA; fkt@rice.edu \\ * Correspondence: zhengchuantao@jlu.edu.cn; Tel.: +86-137-5609-0979
}

Received: 22 September 2018; Accepted: 24 October 2018; Published: 27 October 2018

\begin{abstract}
Incoherent broadband cavity-enhanced absorption spectroscopy (IBBCEAS) is of importance for gas detection in environmental monitoring. This review summarizes the unique properties, development and recent progress of the IBBCEAS technique. Principle of IBBCEAS for gas sensing is described, and the development of IBBCEAS from the perspective of system structure is elaborated, including light source, cavity and detection scheme. Performances of the reported IBBCEAS sensor system in laboratory and field measurements are reported. Potential applications of this technique are discussed.
\end{abstract}

Keywords: incoherent broadband cavity-enhanced absorption spectroscopy (IBBCEAS); molecular spectroscopy; gas sensing; broadband light source; supercontinuum light source

\section{Introduction}

Gas detection and precise quantitative concentration measurements are significant in many applications ranging from chemical analysis to atmospheric pollution monitoring [1-3]. Traditional methods for gas detection are based on the principle of chemical sensing. Samples are taken at a site and are then analyzed in the laboratory, resulting in unpredictable changes in sample quality and delays with respect to on-site processing. Absorption spectroscopy has become the foremost technique for the quantitative assessment of the concentration of atoms and molecules in the gas phase. Due to the advantages of high spatial and temporal resolution, real-time and in-situ measurement, absorption spectroscopy is widely used in the field of trace gas detection [4]. Different spectroscopic approaches for exploiting multiplexing features in a large spectral range have been reported, including cavity ring-down spectroscopy (CRDS) [5-9], cavity-enhanced absorption spectroscopy (CEAS) [10,11] and incoherent broadband cavity-enhanced absorption spectroscopy (IBBCEAS) [12]. These techniques offer different advantages and disadvantages in terms of selectivity, portability, sensitivity and cost.

Among these techniques for spectral absorption measurements, IBBCEAS technique is theoretically straight forward and capable of high sensitivity for trace gas detection. This technique was first reported in 2003 [12] and is based on the detection of the output light from a stable optical cavity with input light from an incoherent broadband light source. In IBBCEAS, a broadband light beam is firstly coupled into an optical cavity formed by two highly-reflective mirrors, and light leaked from the cavity is then dispersed with a grating monochromator and detected by a sensitive photodiode array or charge-coupled device (CCD) array. Concentration level of the gas species can be determined by a least-square algorithm that is commonly used in differential optical absorption spectroscopy (DOAS) $[13,14]$. 
The main advantages of IBBCEAS are as follows: (i) the experimental setup is simple, cost-effective and suitable for field measurements; (ii) no mode matching and mode-hop-free scanning are required, which differs from CEAS; (iii) IBBCEAS can be applied in the spectral range from 190 nm (ultraviolet) to $\sim 10 \mu \mathrm{m}$ (infrared); (iv) multiple gas species can be measured simultaneously in a wide wavelength range. Therefore, IBBCEAS is widely applicable to both existing and new fields of gas sensing, chemical analysis and process control, water and air quality monitoring, remote vegetation sensing as well as explosive detection. This review mainly focuses on the application of IBBCEAS in gas sensing.

The structure of this review is organized as below. The first section covers the evolution of IBBCEAS and its main advantages compared with other techniques. The second chapter summarizes the principle of IBBCEAS for gas sensing. Section 3 describes the progress of IBBCEAS from the perspective of system structure. The fourth chapter focuses on the recent achievement of measurements of different gas species by IBBCEAS and highlights the obtained sensitivity and the minimum detection limit (MDL). Field measurements performances for different target gas species are demonstrated in the fifth section. In the last section, the main factors for performance improvement and the application prospects of the IBBCEAS technique are presented.

\section{Principle of IBBCEAS for Gas Sensing}

In IBBCEAS, the time-integrated light intensity leaked from the cavity is inversely proportional to the absorption coefficient $\alpha$ of a specific gas molecule. The first application of an incoherent light source, a short-arc Xe lamp, was the measurement of the weak absorption of oxygen $\left(\mathrm{O}_{2}\right)$ and of gaseous azulene $\left(\mathrm{C}_{10} \mathrm{H}_{8}\right)$ [12]. A diagram of the light transmission in an optical cavity is shown in Figure 1 . The optical cavity with a length of $\mathrm{d}$ consists of two mirrors with a reflectivity of $R_{1}$ and $R_{2}$, respectively. The input of the incoherent light intensity to the cavity is represented by lin and the mirrors are assumed to absorb no light. Besides the transmission loss $\left(1-R_{i}\right)$, resulting from the imperfect reflectivity of the mirrors, the main loss is the gas absorption $(1-L)$ after each light pass within the cavity. The total light intensity transmitted through the cavity can be expressed as the sum of each individual light intensity leaked from the cavity $[12,15,16]$. In this manner, the cavity output should be detected in wavelength scale by a device which is able to disperse or image the light. Therefore the output light can either be directly focused onto a monochromator with a CCD detector or be imaged onto an interferometer to measure the relation between the leaked light intensity from the cavity and the wavelength.

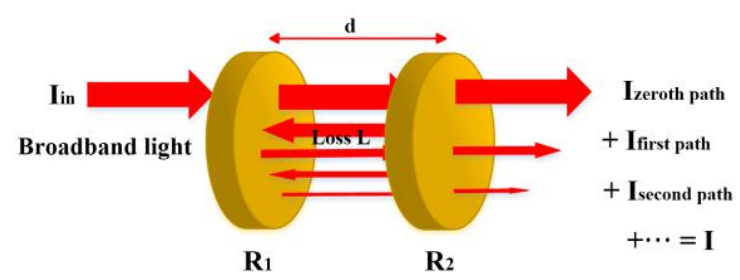

Figure 1. A principle diagram of light transmission in an optical cavity. The input of the broadband light $I_{\text {in }}$ is coupled into an optical cavity with a length of d consists of two mirrors with a reflectivity of $R_{1}$ and $R_{2}$, respectively. Loss $L$ represents the absorption by the target gas species. $I$ is the total light intensity transmitted through the cavity.

The cavity output can be written as

$$
\begin{gathered}
I=I_{\text {in }}\left(1-R_{1}\right)(1-L)\left(1-R_{2}\right)+I_{\text {in }}\left(1-R_{1}\right)(1-L) R_{2}(1-L) R_{1}(1-L)\left(1-R_{2}\right) \\
+\cdots+I_{\text {in }}\left(1-R_{1}\right)\left(1-R_{2}\right) R_{1}^{n} R_{2}^{n}(1-L)^{2 n+1}+\cdots+ \\
=I_{\text {in }}\left(1-R_{1}\right)\left(1-R_{2}\right)(1-L) \sum_{n=0}^{\infty} R_{1}^{n} R_{2}^{n}(1-L)^{2 n}
\end{gathered}
$$


Since $R_{1}<1, R_{2}<1$ and $L<1$, Equation (1) can be written as

$$
I=I_{\text {in }} \frac{\left(1-R_{1}\right)\left(1-R_{2}\right)(1-L)}{1-R_{1} R_{2}(1-L)^{2}}
$$

For a cavity without absorption loss, i.e., $L=0$, Equation (2) can be simplified to

$$
I=I_{\text {in }} \frac{\left(1-R_{1}\right)\left(1-R_{2}\right)}{1-R_{1} R_{2}}
$$

Consequently, the single-pass loss can be expressed as the difference between the light intensity measured in a cavity filled with a target gas $(I)$ and that without the gas $\left(I_{0}\right)$

$$
1-L= \pm \sqrt{\frac{1}{4}\left(\frac{I_{0}}{I} \frac{1-R_{1} R_{2}}{R_{1} R_{2}}\right)^{2}+\frac{1}{R_{1} R_{2}}}-\frac{1}{2} \frac{I_{0}}{I} \frac{1-R_{1} R_{2}}{R_{1} R_{2}}
$$

Assuming that the single-path loss is related to Lambert-Beer law as $1-L=\exp (-\alpha d)$ and $R_{1}=R_{2}=R$, the absorption coefficient $\alpha$ can be written in the following form:

$$
\alpha=\frac{1}{d}\left|\ln \left(\frac{1}{2 R^{2}}\left(\sqrt{4 R^{2}+\left(\frac{I_{0}}{I}\left(R^{2}-1\right)\right)^{2}}+\frac{I_{0}}{I}\left(R^{2}-1\right)\right)\right)\right|
$$

It should be noted that the derivation of Equation (5) does not use any approximation related to $\alpha$ and $R$, and thus even in the condition of a large $\alpha$ and a small $R$, Equation (5) is applicable. In case of a small loss per pass $(L \rightarrow 0)$ and a high reflectivity of the mirrors $(R \rightarrow 1), \alpha$ can be approximated by:

$$
\alpha \approx \frac{1}{d}\left(\frac{I_{0}}{I}-1\right)(1-R)
$$

Equation (6) indicates that the effective path length in IBBCEAS can be increased by a factor of $(1-R)^{-1}$ in comparison to single-pass. The effective absorption path length is $\left(1-\sqrt{R_{1} R_{2}}\right)^{-1}$ times that of a single-pass in case of a general condition of $R_{1} \neq R_{2}$. Furthermore, the signal-to-noise ratio (SNR) is increased by a factor of $[2(1-R)]^{-1 / 2}$ [17]. Fiedler et al. [12] studied the impact of mirror reflectivity, cavity length and light injection pattern on the cavity output [18], which clearly demonstrated the relationship between these parameters.

Given the measured mirror reflectivity $R$ and cavity length $d$, the target gas concentration can be retrieved by a least-square fitting algorithm [19]. As shown in Figure 2, the main concept of this method is fitting the cross-section $\sigma$ of the target gas to the experimentally measured absorption coefficient $\alpha$ as [9]

$$
\alpha=\sum_{i} n_{i} \cdot \sigma_{i}+a \lambda^{2}+b \lambda+c
$$

where $\sigma_{i}$ represents the reference cross-section of the $i$ th gas species, which should be convoluted with the measurement instrument function and can be obtained from the HITRAN database, $n_{i}$ is the concentration of the $i$ th gas species. The second-order polynomial $a \lambda^{2}+b \lambda+c$ represents the background baseline, which could arise from the light source intensity and cavity coupling variations over the time, mechanical vibration, gas scattering including Rayleigh and Mie scattering, aerosol extinction and system drifts. This fitting method is widely used in DOAS for spectral fitting, which is rather effective in retrieving concentrations even in cases where the spectrum appears noisy and shows baseline drifts. The unknown parameters $\left(n_{i}, a, b\right.$ and $\left.c\right)$ can be extracted using a linear algebraic method such as the singular value decomposition (SVD) method or nonlinear Levenberg-Marquardt routine for real-time concentration retrieval. Temperature and pressure mainly affect the shape and profile 
of the absorption line. When we convolute the instrument function with the reference cross-section, temperature and pressure broadening effect should be taken into account.

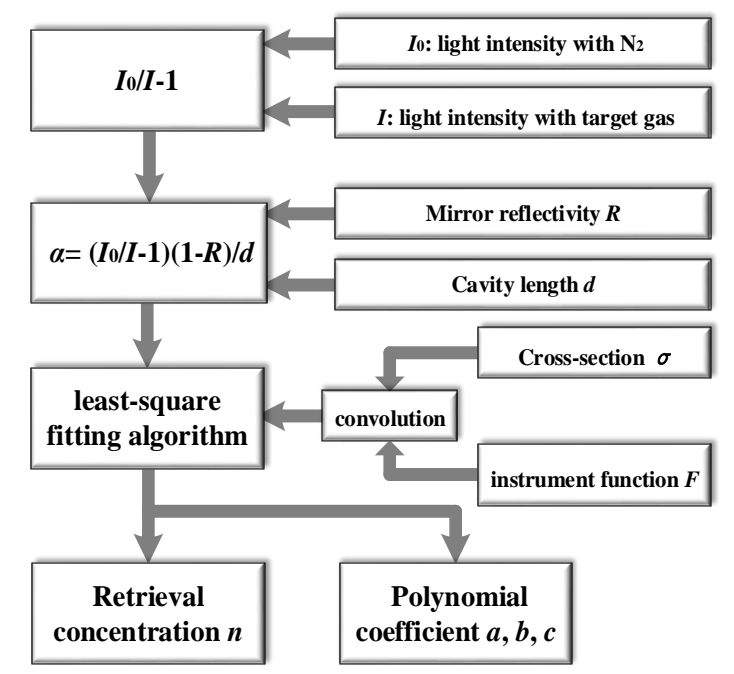

Figure 2. Concentration retrieval procedure for IBBCEAS.

\section{Experimental Aspects}

Figure 3 shows a schematic diagram of a general IBBCEAS set-up. A broadband light source can be a short-arc Xe lamp, a light emitting diode (LED) or a supercontinuum (SC) source. The incoherent light is coupled directly from the source into an optical fiber. The emerging light from the fiber was collimated with a lens and then injected into a high-finesse optical cavity. A filter was located in front of the cavity, in order to remove the wavelength components outside the highly reflective range. The optical cavity is formed by two reflective dielectric mirrors separated by a specific distance. The beam in the cavity is reflected between the two mirrors, resulting in an improvement of the effective optical path length. For a close-path configuration, the sample flow is controlled by means of a mass flow controller at the inlet of the cavity. A pump and a pressure gauge are used at the outlet to pump the target gas into the cell and to control the gas pressure inside the cavity, respectively. In addition, purified gas (such as $\mathrm{N}_{2}$ ) is introduced adjacent to both mirrors in order to prevent mirror pollution by aerosol deposition and volatile organic compounds (VOCs). For an open-path configuration, none of these devices described above is needed. Light transmitted through the cavity is focused with a lens and coupled into an optical fiber. The fiber output can be directly connected to a CCD spectrometer or imaged onto an interferometer. The length of the cavity and the radius of curvature of the mirror determine the volume of the chamber.

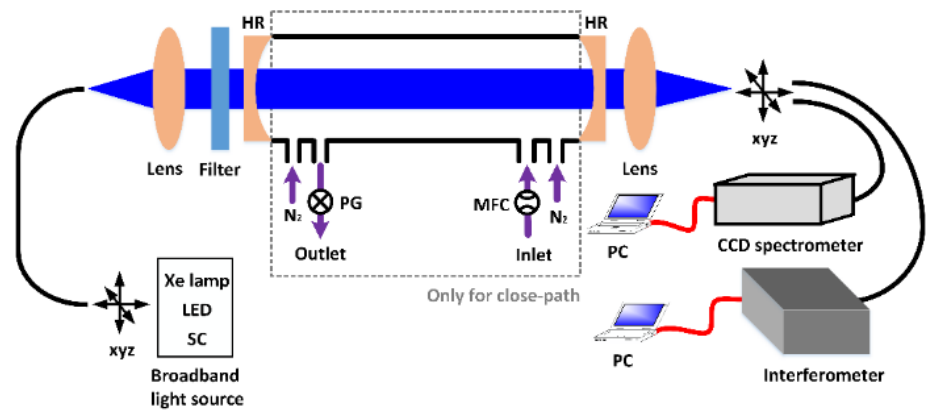

Figure 3. Schematic diagram of a typical IBBCEAS setup. HR is a high-reflectivity mirror used to form an optical cavity. CCD spectrometer is a charge-coupled device spectrometer. PC is a personal computer for data processing. PG represents the pressure gauge and MFC is the mass flow controller. The dashed box refers to the structure of the close-path cavity, which is unnecessary for an open-path configuration. 
Fang et al. [20] reported a novel IBBCEAS instrument utilizing a custom cage optical system with a size of $676 \mathrm{~mm} \times 74 \mathrm{~mm} \times 86 \mathrm{~mm}$ and a weight of $4.5 \mathrm{~kg}$. The sensor system for transmitter (LED output) and receiver units (CCD spectrometer) were interchangeable, which realized a compact and stable optical system that could be easily aligned. In the following Sections 3.1-3.3, we will describe the development of IBBCEAS from the perspective of system structure, including light source, cavity and detection scheme.

Table 1 shows the important items (light source, cavity and detection scheme) used in IBBCEAS and the corresponding advantages and disadvantages. With respect to long-term test and gas sensing in field application, the system configuration combining an LED with a CCD spectrometer maybe more suitable since they are more cost-effective, faster as well as more portable for mobile deployment. For high-resolution spectral measurements, the SC source based Fourier-transform spectrometer (FTS) is more preferable due to the ultrahigh-resolution of the FTS with a high brightness of the SC source.

Table 1. Reported light source, cavity and detection scheme used in IBBCEAS.

\begin{tabular}{|c|c|c|c|c|}
\hline Items & Classification & Reference & Advantages & Disadvantages \\
\hline \multirow{5}{*}{ Light Source } & \multirow{2}{*}{$\begin{array}{l}\text { Short-arc Xe } \\
\text { lamp }\end{array}$} & Fiedler et al. (2003) & high spectral brightness; & intensity fluctuations; \\
\hline & & $\begin{array}{l}\text { Ashu-Ayem et al. } \\
\text { (2012) }\end{array}$ & broad spectral region; & high energy consumption; \\
\hline & & Wu et al. (2009) & $\begin{array}{l}\text { high brightness, low power } \\
\text { consumption; }\end{array}$ & \multirow[t]{2}{*}{$\begin{array}{l}\text { sensitive to temperature } \\
\text { and current fluctuations; }\end{array}$} \\
\hline & & Wang et al. (2017) & $\begin{array}{l}\text { narrow full width at half } \\
\text { maximum (FWHM); }\end{array}$ & \\
\hline & SC source & $\begin{array}{l}\text { Chandran et al. } \\
\qquad(2016)\end{array}$ & $\begin{array}{l}\text { high power density and } \\
\text { broadband wavelength } \\
\text { coverage; }\end{array}$ & $\begin{array}{l}\text { unstable in a long } \\
\text { acquisition periods } \\
\text { and costly }\end{array}$ \\
\hline \multirow{5}{*}{ Cavity Scheme } & \multirow{2}{*}{ Closed-path } & $\begin{array}{l}\text { Gherman et al. } \\
(2008)\end{array}$ & \multirow{2}{*}{$\begin{array}{l}\text { enabling the design of a portable } \\
\text { system with good mechanical } \\
\text { stability and compactness; }\end{array}$} & \multirow[t]{2}{*}{$\begin{array}{l}\text { wall losses for different } \\
\text { target species; }\end{array}$} \\
\hline & & Amiot et al. (2017) & & \\
\hline & \multirow{3}{*}{ Open-path } & Varma et al. (2009) & simple calibration procedure; & $\begin{array}{l}\text { at a high aerosol } \\
\text { concentration levels, }\end{array}$ \\
\hline & & Ling et al. (2013) & $\begin{array}{l}\text { free from wall loss of target } \\
\text { species; }\end{array}$ & $\begin{array}{l}\text { the concentration retrieval } \\
\text { is challenging; }\end{array}$ \\
\hline & & $\begin{array}{c}\text { Nakashim et al. } \\
\text { (2017) }\end{array}$ & $\begin{array}{l}\text { arbitrarily extended cavity } \\
\text { length; }\end{array}$ & $\begin{array}{l}\text { a reference spectrum } I_{0} \text { is } \\
\text { not available; }\end{array}$ \\
\hline \multirow{4}{*}{ Detection Scheme } & \multirow{2}{*}{$\begin{array}{l}\text { dispersive } \\
\text { approaches }\end{array}$} & $\begin{array}{l}\text { Kennedy et al. } \\
\quad(2011)\end{array}$ & \multirow{2}{*}{$\begin{array}{l}\text { rapid detection over a wide } \\
\text { wavelength range with a } \\
\text { multi-channel detector; }\end{array}$} & \multirow[t]{2}{*}{$\begin{array}{l}\text { low spectral resolution of } \\
\sim 0.1 \mathrm{~nm} \text { and } \sim 1 \mathrm{~nm} ;\end{array}$} \\
\hline & & Liang et al. (2017) & & \\
\hline & \multirow{2}{*}{$\begin{array}{l}\text { interferometric } \\
\text { approaches }\end{array}$} & Orphal et al. (2008) & \multirow{2}{*}{$\begin{array}{l}\text { high resolution and sensitivity } \\
\text { of } \sim 0.02 \mathrm{~cm}^{-1} \text { and } \sim 4 \mathrm{~cm}^{-1} \\
\text { from VIS to near-IR range; }\end{array}$} & long acquisition time; \\
\hline & & Denzer et al. (2011) & & not compact and costly; \\
\hline
\end{tabular}

\subsection{Light Source}

The choice of a broadband light source depends crucially on its application and also impinges on the SNR of a sensor system. Generally, the favorable attributes of a light source should include robustness, low cost, long lifetime, and high photon fluence with enough SNR to allow for adequate coupling efficiency of the broadband light to a high-finesse cavity. In addition, it should have a wide emission spectrum in the wavelength range of interest for the purpose of a high degree of flexibility in terms of switching among different excitation ranges. Also, a high emission stability and a low spectral drift are of importance for achieving a good sensor performance. However, no broadband light source meets all these requirements and thus some of these properties will be a compromise. Figure 4 shows the scale of time where different type of light sources was adopted to implement IBBCEAS. This is followed by a summary of the main characteristics of light sources commonly used in IBBCEAS. 


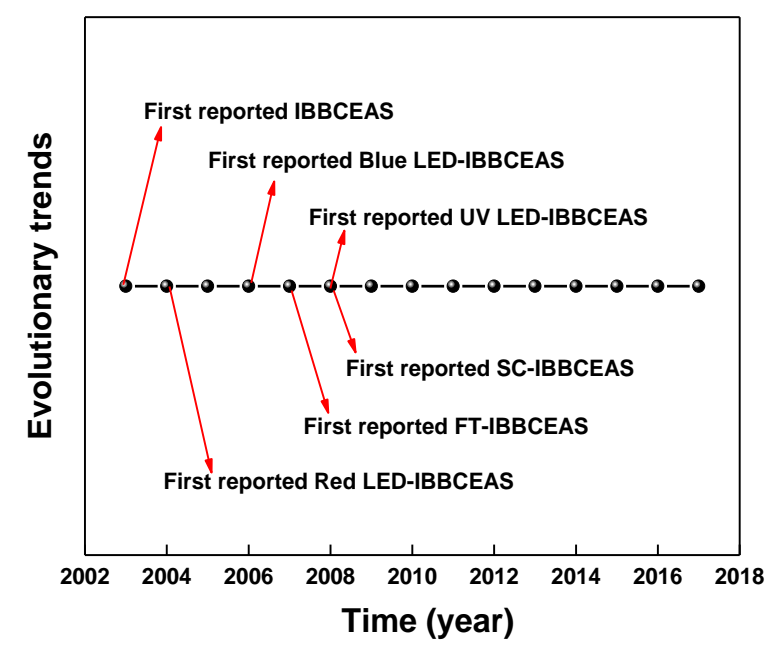

Figure 4. Time scale where different types of sources were firstly used to implement IBBCEAS since 2003

\subsubsection{Short-Arc Xe Lamp}

An arc lamp emits white light covering a wide spectral region from the ultraviolet (UV) to the near-infrared (near-IR) [21]. Due to the high spectral brightness and low intensity fluctuations, Xe lamp-based IBBCEAS was firstly demonstrated in 2003 [12]. A short-arc Xe lamp with a specified luminosity of $18 \mathrm{~W} \cdot \mathrm{cm}^{-2} \cdot \mathrm{sr}^{-1} \cdot \mathrm{nm}^{-1}$ at $400 \mathrm{~nm}$ with specific optical filter and fluctuations of up to $\sim 10 \%$ was successfully employed. Since then, this kind of light source has been used in numerous applications using IBBCEAS [9,12,22-32]. Varma et al. [9] placed a $75 \mathrm{~W}$ Xe lamp in a water-cooled housing with an F/2 ellipsoidal reflector in order to stabilize the light source and improve the light collection efficiency. High-resolution applications in IBBCEAS usually require a Fourier transform spectrometer. By adopting a small-volume chamber, Orphal et al. [23] reported the first application of the combination of Fourier transform spectroscopy (FTS) and IBBCEAS in the near-IR band ranging from $5800 \mathrm{~cm}^{-1}$ to $7000 \mathrm{~cm}^{-1}$. Utilizing a long averaging time, high-frequency noise introduced by the lamp fluctuation was avoided.

\subsubsection{LED}

LEDs, which are widely used nowadays in multi-media and lighting, are available for the spectral region from the near-UV to the near-IR. And such a wide spectral range allow access to almost all molecules exhibiting strong absorption arising from fundamental vibrational-rotational transitions with a specific molecular signature [33]. Due to high brightness, low power consumption, narrow full width at half maximum (FWHM) and long life time, LEDs are suitable for IBBCEAS applications in the sensitive detection of numerous important atmospheric trace gas species and pollutant gases. The first application of LEDs for IBBCEAS was demonstrated by Ball et al. [34] used red and green LEDs with different optical filters. Since then, LED-based IBBCEAS have been widely applied in IBBCEAS for multiple trace gas detection ranging from near-UV to the visible (VIS) band. Furthermore, it should be noted that LEDs are sensitive to temperature fluctuations and hence adequate temperature and current stabilization in gas detection are required.

Superluminescent LEDs (SLEDs) have shown to be a good choice for IR gas sensing since their emission wavelengths correspond to the high reflectivity of the cavity mirrors. They are based on the generation and amplification of spontaneous emission in a semiconductor waveguide. In addition, a SLED has a relatively high spectral power density and a high spatial coherence in the near-IR range. However, SLEDs have not been widely adopted as light sources for IBBCEAS measurements to-date $[35,36]$. 


\subsubsection{SC Source}

SC radiation sources are attractive and broadly used in spectroscopic applications, such as in physics, chemistry and biology [37-40], owing to the combination of high power density and wideband wavelength coverage [41]. A supercontinuum excitation source requires a seed laser with a high repetition rate that determines the SC mode spacing and an achromatic lens to collimate the SC radiation. Light exits the photonic crystal fiber (PCF) into a beam shows a high power density and an ultra-wide spectral region access.

The application of SC light source for IBBCEAS was first demonstrated by Langridge et al. [42] for the quantitative measurements of $\mathrm{NO}_{2}$ and $\mathrm{NO}_{3}$. Other reports of SC sources applied in IBBCEAS are within the VIS to the near-IR regions. An interesting approach to create continuum radiation for IBBCEAS was presented by Ruth et al. [43], by using a short-pulse laser to stimulate a high-temperature black body inside the cavity. This method generates SC radiation directly in the cavity instead of using a PCF, resulting in a consecutive emission of the light and notable enhancement of coupling efficiency.

\subsection{Cavity Scheme}

The most common reported geometry of a cavity for gas sensing is the conventional linear mirror cavity formed by two highly reflective mirrors separated by a specific distance. The target gas can be continuously pumped from a sample volume and injected into the cavity through a closed-path cavity configuration. Alternatively, some atmospheric monitoring applications use an open-path configuration, especially for in-situ field measurements together with an atmospheric simulation chamber. Both closed-path and open-path configurations present advantages and drawbacks for trace gas sensing.

\subsubsection{Closed-Path Configuration}

Zhao et al. demonstrated. a closed-path configuration with a typical cavity length of $\sim 1 \mathrm{~m}$ [19], which enables a portable broadband sensor system with good mechanical stability and compactness. A major advantage of a closed cavity is that the calibration of the mirror reflectivity can be measured by filling the cavity with a calibration gas (for CEAS applications) or zero air (for CRD applications). Furthermore, optical loss of aerosol can be eliminated by filtering the pumped gas sample on the inlet side. Teflon polytetrafluoroethylene (PTFE) filter was adopted by a majority of reported systems to remove ambient aerosols $[19,44,45]$.

The main drawback of the closed-path system is related to the wall losses for different target gas species [46]. They occur on the inlet side and on the wall of the enclosed cavity over time, especially for some "sticky" gases, such as $\mathrm{NO}_{2}$ and $\mathrm{NH}_{3}$ etc. Most of the reported chambers are made of Perfluoroalkoxy alkanes (PFA) to minimize gas loss during detection. For the sake of mirror protection, a small purge flow of zero air or $\mathrm{N}_{2}$ is usually used on both sides of the cavity.

\subsubsection{Open-Path Configuration}

Unlike an enclosed cavity, an instrument using an open-path cavity is free from wall losses of the target gas species, as reported by Wu et al. [47]. Since the cavity mirrors are not fixed, the cavity length can be extended arbitrarily, which improves the sensor sensitivity. Moreover, a long cavity enables the use of mirrors with a low reflectivity without decreasing the SNR of the cavity transmission and the retrieval accuracy of the target gas species.

However, for high aerosol concentration levels, the concentration retrieval of the target gas species may be challenging, owing to the significant reduction of the effective optical path length for open-path configurations. Moreover, another drawback of open-path configuration is the unavailability of a "clean air" reference spectrum $I_{0}$, which is problematic for mirror reflectivity calibration and concentration measurements. But in simulation chambers $[9,25,31]$ with open-path configuration, this issue can be solved in the way of filling the chamber with a calibration gas or zero-air. 


\subsection{Detection Scheme}

In terms of detection scheme, the light transmitted through the cavity can either be directly focused onto the entrance aperture of a monochromator equipped with a CCD detector or be imaged onto the entrance aperture of an interferometer. Pros and cons of the two methods will be presented in Section 3.3.

\subsubsection{Dispersive Approach}

The light leaking out of the cavity is either coupled into a fiber attached to a monochromator or directly focused onto the entrance slit of a monochromator. Dispersive optical elements, typically a reflective grating, usually choose a single order and are then imaged onto a CCD array. The spectral resolution is usually determined by the monochromator's slit width, the groove density of the grating and the distance between the injection point and the CCD detector in conjunction with its pixel size. Spectral resolutions between $\sim 0.1 \mathrm{~nm}$ and $\sim 1 \mathrm{~nm}$ are sufficient to resolve broadened spectral features in the UV-VIS range $[9,10]$. Due to a high response speed of the CCD, this method processes a merit of rapid detection over a wide spectral range but is not able to perform high-resolution spectroscopic detection.

\subsubsection{Interferometric Approach}

The light transmitted through the cavity is imaged into an interferometer, and is then separated by a beam splitter. A continuously moving mirror shifts back and forth along the optical axis, making the light travel over different path lengths inside the interferometer. The optical path difference between the two light beams is periodically changed and interference occurs. The interference signal is converted into an electrical signal by a single-channel detector, and a digital interferogram is obtained by means of an analog-to-digital (A/D) converter. Finally, the spectrum information is reconstructed after performing the Fourier Transform on the recorded interferogram. The spectral resolution is determined by the size of the aperture and the maximum path length difference caused by the two interfering beams. The typical resolution of IBBCEAS is between $0.02 \mathrm{~cm}^{-1}$ and $4 \mathrm{~cm}^{-1}$ from the VIS to the near-IR range. However, high resolution and sensitivity come at the expense of rather long acquisitions times. But such approaches are suitable for chemical flow reactors that require small sample volume, and can accurately measure the spectrum of a gas molecule.

Fourier-transform IBBCEAS (FT-IBBCEAS) was first demonstrated by Ruth et al. [22] by using a commercial FTS in a standard IBBCEAS setup using short-arc Xe lamp as light source. The spin-forbidden B-band of gaseous oxygen at $688 \mathrm{~nm}$ as well as the weak absorption transitions of water vapor was measured. The absorption spectra of the overtone bands of $\mathrm{CO}_{2}, \mathrm{OCS}$ and $\mathrm{HD}^{18} \mathrm{O}$ in the near-IR were also detected in further FT-IBBCEAS studies [23].

\section{Target Gas Species Performances in Laboratory}

There is a substantial increment in the quantity of literature reporting IBBCEAS and its variants techniques over the past decade. IBBCEAS has been successfully applied in atmospheric and environmental measurements [48,49]. Trace gas species are usually involved in the atmospheric chemical cycle and have a residence time in the atmosphere of a few days to several decades or even longer. Some gas species are naturally generated by human activities. They are subject to physical, chemical, biological earth processes and are involved in biogeochemistry circulation, such as $\mathrm{NO}_{3}$, $\mathrm{NO}_{2}, \mathrm{I}_{2}, \mathrm{CHOCHO}$ and $\mathrm{CO}_{2}$. This section attempts to review the latest research and development of trace gas detection in laboratory using the IBBCEAS technique, including proof-of-principle of this technique, multiple and single target gas detection. Spectra of key atmospheric molecular species in the UV and VIS region are depicted in Figure 5. In Table 2, it shows the performances of the reported IBBCEAS instrument for key gas species detection. 


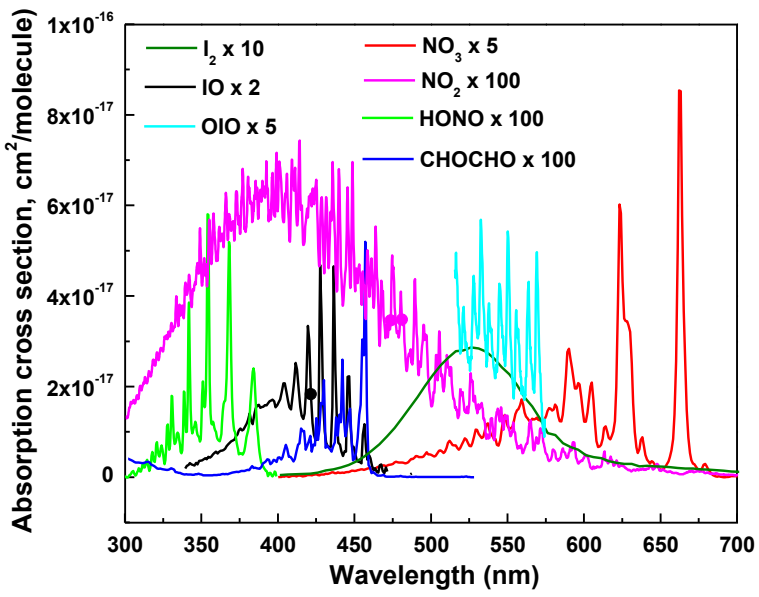

Figure 5. Spectra of key atmospheric molecular species in the UV and VIS region $(\times 10$ means the cross section is multiplied by ten times, and so on).

Table 2. Performances of the IBBCEAS instrument for target gas species in laboratory.

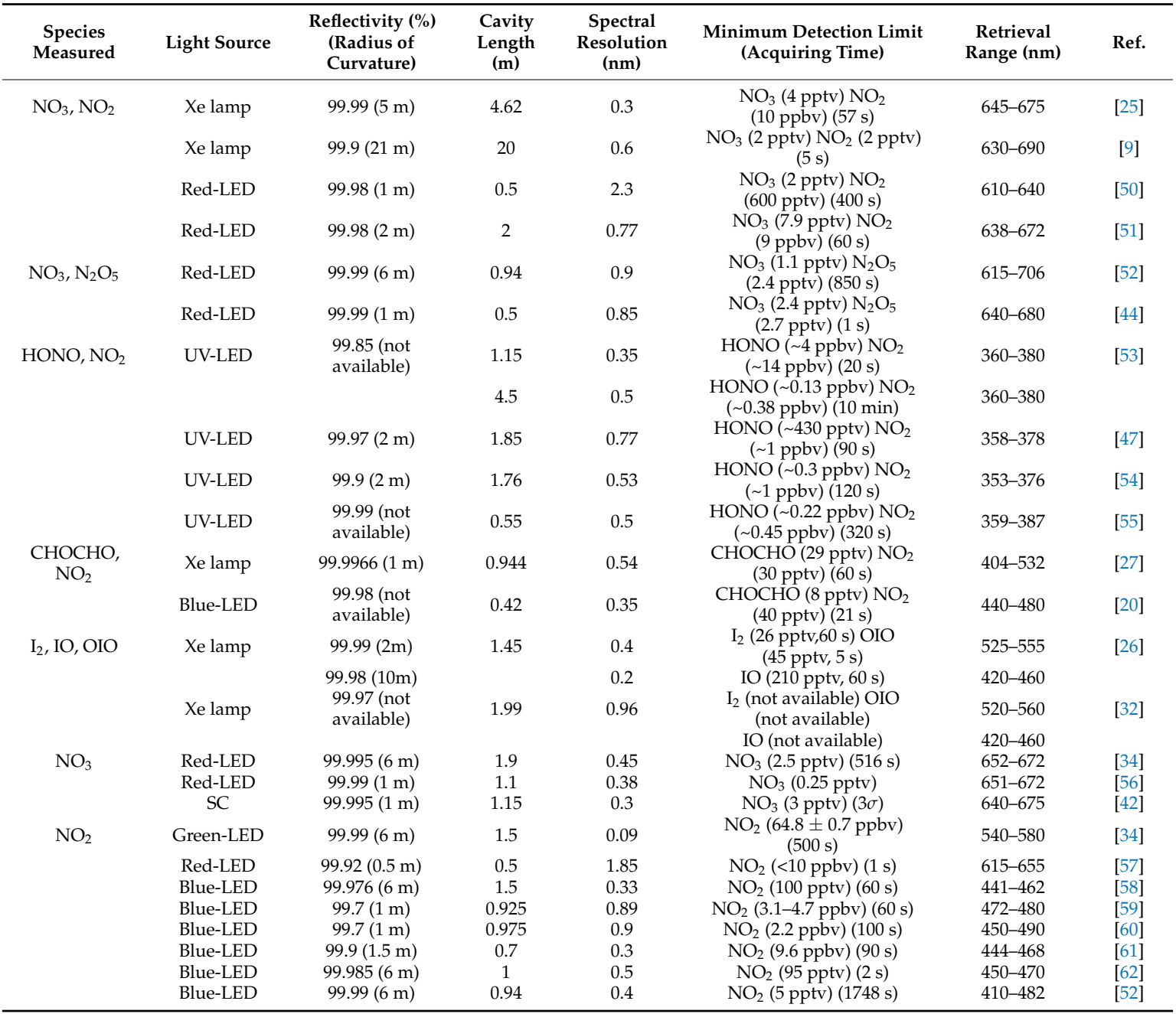


Table 2. Cont.

\begin{tabular}{|c|c|c|c|c|c|c|c|}
\hline $\begin{array}{l}\text { Species } \\
\text { Measured }\end{array}$ & Light Source & $\begin{array}{c}\text { Reflectivity (\%) } \\
\text { (Radius of } \\
\text { Curvature) }\end{array}$ & $\begin{array}{l}\text { Cavity } \\
\text { Length } \\
\text { (m) }\end{array}$ & $\begin{array}{c}\text { Spectral } \\
\text { Resolution } \\
\text { (nm) }\end{array}$ & $\begin{array}{l}\text { Minimum Detection Limit } \\
\text { (Acquiring Time) }\end{array}$ & $\begin{array}{c}\text { Retrieval } \\
\text { Range }(\mathrm{nm})\end{array}$ & Ref. \\
\hline HONO & UV-LED & $\begin{array}{c}99.985 \\
\text { (not available) }\end{array}$ & 1 & 0.5 & $\mathrm{HONO}(\sim 0.2 \mathrm{ppbv})(5 \mathrm{~min})$ & $360-375$ & [63] \\
\hline $\mathrm{I}_{2}$ & $\begin{array}{l}\text { Green-LED } \\
\text { Green-LED }\end{array}$ & $\begin{array}{l}99.99(6 \mathrm{~m}) \\
99.99(1 \mathrm{~m})\end{array}$ & $\begin{array}{l}1.5 \\
0.5\end{array}$ & $\begin{array}{c}0.09 \\
0.5\end{array}$ & $\begin{array}{l}\mathrm{I}_{2}(991 \pm 11 \mathrm{pptv})(300 \mathrm{~s}) \\
\mathrm{I}_{2}(0.04 \mathrm{nmol} / \mathrm{L}, \sim 1 \mathrm{ppbv})\end{array}$ & $\begin{array}{l}530-565 \\
500-550\end{array}$ & $\begin{array}{l}{[34]} \\
{[64]}\end{array}$ \\
\hline $\mathrm{C}_{4} \mathrm{H}_{6}$ & SLED & $\begin{array}{l}99.98(\text { not } \\
\text { available) }\end{array}$ & 0.25 & $\begin{array}{l}1.8 \mathrm{~cm}^{-1} \\
0.5 \mathrm{~cm}^{-1}\end{array}$ & $\begin{array}{c}\text { dispersive spectrometer } \\
\left(6.1 \times 10^{-8} \mathrm{~cm}^{-1}\right) \\
\text { FTS }\left(1.5 \times 10^{-8} \mathrm{~cm}^{-1}\right)\end{array}$ & $1620-1700$ & [35] \\
\hline $\mathrm{C}_{4} \mathrm{H}_{8} \mathrm{O}_{2}$ & SC & $99.9(6 \mathrm{~m})$ & 6.44 & $0.08 \mathrm{~cm}^{-1}$ & $\begin{array}{c}8 \times 10^{-8} \mathrm{~cm}^{-1}(\sim 200 \mathrm{pptv} \\
120 \mathrm{~min})\end{array}$ & $1215-1700$ & [65] \\
\hline
\end{tabular}

\subsection{Proof-of-Principle of the IBBCEAS $\left(\mathrm{O}_{2}, \mathrm{C}_{10} \mathrm{H}_{8}, \mathrm{CO}_{2}, \mathrm{OCS}, \mathrm{HD}^{18} \mathrm{O}\right)$}

The proof-of-principle of the IBBCEAS technique can be demonstrated by measuring the weak atmospheric transition of various materials, such as the $b^{1} \sum_{g}^{+}\left(v^{\prime}=2\right) \leftarrow X^{3} \sum_{g}^{-}\left(v^{\prime \prime}=0\right)$ absorption transition of $\mathrm{O}_{2}$ and the $S_{1, v^{\prime}} \leftarrow S_{0}$ absorption spectrum of azulene at its vapour pressure at room temperature. In addition, absorption spectra in the overtone bands of $\mathrm{CO}_{2}, \mathrm{OCS}$ and $\mathrm{HD}^{18} \mathrm{O}$ were also measured using the IBBCEAS technique.

In 2003, Fiedler et al. [12] demonstrated a new highly-sensitive IBBCEAS using a short-arc Xe lamp with a $45 \mathrm{~cm}$-long cavity, and the output light was detected by a grating monochromator equipped with a photodiode array. The absorption spectrum of the $b\left(v^{\prime}=2\right) \leftarrow X\left(v^{\prime \prime}=0\right)$ transition $(\mathrm{Q} / \mathrm{R}$ and part of $\mathrm{P}$ branch) of $\mathrm{O}_{2}$ at 1000 mbar in a static cell between $628 \mathrm{~nm}$ and $630 \mathrm{~nm}$ was measured with IBBCEAS at a $25 \mathrm{~s}$ averaging time, together with the $S_{1} \leftarrow S_{0}$ absorption spectrum of gaseous azulene at an averaging time of $90 \mathrm{~s}$, resulting in an absorption coefficient of $1.3 \times 10^{-5} \mathrm{~cm}^{-1}$ within the $628 \mathrm{~nm}$ and $670 \mathrm{~nm}$ spectral range.

For high resolution applications requiring Fourier transform detection, a new design of IBBCEAS was proposed in 2007. Ruth et al. [22] adopted a commercial FTS in a standard IBBCEAS set-up in place of a monochromator using a short-arc Xe lamp. This new technique, named FT-IBBCEAS, was applied for measuring the transition of $b^{1} \sum_{g}^{+}\left(v^{\prime}=1\right) \leftarrow X^{3} \sum_{g}^{+}\left(v^{\prime \prime}=0\right)$ of $\mathrm{O}_{2}$ at $\sim 688 \mathrm{~nm}$ and several transitions of $\mathrm{H}_{2} \mathrm{O}$ in ambient air at $\sim 720 \mathrm{~nm}$, leading to a path-length enhancement factor of 200 and a SNR improvement of $\sim 6$ compared to the single-pass absorption measurement. In 2008, the same group [23] extended the spectral region to the near-IR, and the absorption spectra of the overtone bands of $\mathrm{CO}_{2}$, OCS, and $\mathrm{HD}^{18} \mathrm{O}$ were measured between $5800 \mathrm{~cm}^{-1}$ and $7000 \mathrm{~cm}^{-1}$ with a data acquisition time of $90 \mathrm{~min}$. Furthermore, it was demonstrated that the high-resolution spectra provided an improved method to calibrate mirror reflectivity or an absolute absorption cross-section without measuring an empty cavity using a small sampling volume, but at the expense of time resolution.

A new method in the application of IBBCEAS for measuring the absorption spectrum of $\mathrm{C}_{10} \mathrm{H}_{8}$ as well as the $b^{1} \sum_{g}^{+}\left(v^{\prime}=2\right) \leftarrow X^{3} \sum_{g}^{-}\left(v^{\prime \prime}=0\right)$ of $\mathrm{O}_{2}$ was demonstrated by Ruth et al. [43] in 2015. The main idea was to place a laser-induced gas plasma, generated by a short pulse laser, in the center of a quasi-confocal high-finesse cavity, which was used as the pulsed incoherent broadband light source. The light emission was sustained by the cavity despite the initially large optical loss. Experiments demonstrated a good agreement $\left(R^{2}=0.9985\right)$ in measuring part of the absorption spectrum of $\mathrm{C}_{10} \mathrm{H}_{8}$ and the strongly forbidden $\gamma$-band in $\mathrm{O}_{2}$ compared with the CRDS in the same region [66].

\subsection{Multiple Target Gas Detection}

\subsubsection{Simultaneous Detection of $\mathrm{NO}_{3}$ and $\mathrm{NO}_{2}$}

Reliable concentration assessment of the major atmospheric oxidants and their precursors is essential to advance our understanding of chemical process in the troposphere [25,67-71]. 
Most reported IBBCEAS set-ups for simultaneous detection of $\mathrm{NO}_{3}$ and $\mathrm{NO}_{2}$ are in a spectral range of 610-690 nm using Xe lamps and LEDs.

In 2006, Venables et al. [25] used a $75 \mathrm{~W}$ Xe lamp source and a $462 \mathrm{~cm}$ atmospheric simulation chamber with two mirrors ( $R \sim 99.775 \%)$. The cavity output was directed into a spectrograph equipped with a CCD detector. A sensitivity of 4 pptv for $\mathrm{NO}_{3}$ and 10 ppbv for $\mathrm{NO}_{2}$ was obtained between $620 \mathrm{~nm}$ and $690 \mathrm{~nm}$ in a $1 \mathrm{~min}$ acquisition time. In 2009, Varma et al. [9] used a $20 \mathrm{~m}$-long optical cavity to detect $\mathrm{NO}_{3}$ and $\mathrm{NO}_{2}$ between $630 \mathrm{~nm}$ and $690 \mathrm{~nm}$. The reported MDL, defined as the minimum concentration level that can be detected by the sensor, was experimentally determined to be $\sim 2 \mathrm{pptv}$ for $\mathrm{NO}_{3}$ and 2 parts-per-billion in volume (ppbv) for $\mathrm{NO}_{2}$ with an acquisition time of $5 \mathrm{~s}$. In 2010, a progress in cavity length stated to be $50 \mathrm{~cm}$ was proposed by Triki et al. [50]. Furthermore, they also improved their set-up reported before [57] by connecting an optical fiber to a spectrometer, which degraded the spectrometer resolution from $\sim 1.8 \mathrm{~nm}$ to $\sim 2.3 \mathrm{~nm}$ but dramatically increased the light intensity on the CCD array. A MDL of 2 pptv for $\mathrm{NO}_{3}$ and 600 pptv for $\mathrm{NO}_{2}$ were achieved with a $\sim 400 \mathrm{~s}$ averaging time. In 2014, Wu et al. [51] proposed an experiment using an atmospheric chamber $\left(8 \mathrm{~m}^{3}\right)$ using a cavity with mirrors of a reflectivity of $99.991 \%$ between $638 \mathrm{~nm}$ and $672 \mathrm{~nm}$, leading to a maximum effective optical path length of $22 \mathrm{~km}$. In this paper, an IBBCEAS instrument was used in a simulation chamber to monitor $\mathrm{NO}_{3}, \mathrm{NO}_{2}$ concentration levels in chemical reaction. The reported MDL for $\mathrm{NO}_{3}$ and $\mathrm{NO}_{2}$ were 7.9 pptv and 9.0 ppbv respectively with an acquisition time of $60 \mathrm{~s}$.

\subsubsection{Simultaneous Detection of $\mathrm{NO}_{3}$ and $\mathrm{N}_{2} \mathrm{O}_{5}$}

For simultaneous detection of $\mathrm{NO}_{3}$ and $\mathrm{N}_{2} \mathrm{O}_{5}$, most IBBCEAS devices are within $615-706 \mathrm{~nm}$ using red LEDs. A novel application in IBBCEAS instrumentation was reported by Kennedy et al. [52] with the idea of airborne measurements in night time using three channels (i.e., three cavities) in an IBBCEAS instrument. The advancement in this paper was to establish a new clever way in which the mirror reflectivity can be determined. Channel one and two are used for $\mathrm{NO}_{3}$ and $\mathrm{N}_{2} \mathrm{O}_{5}$ detection with two red LEDs centered at $685 \mathrm{~nm}$. The $1 \sigma$ standard deviation indicated a MDL for $\mathrm{N}_{2} \mathrm{O}_{5}$ of 2.4 pptv and for $\mathrm{NO}_{3}$ of 1.1 pptv, with an uncertainty of $14 \%$ and $11 \%$, respectively. In 2017, Wang et al. [44] demonstrated a set-up based on a 665-nm LED with a $50 \mathrm{~cm}$-long cavity formed by two mirrors (R 99.99\%). This work focused on the simultaneous detection of $\mathrm{NO}_{3}$ and $\mathrm{N}_{2} \mathrm{O}_{5}$. The instrument reported a novel design of mechanically aligned non-adjustable optical mounting system, which enabled a fast set-up and a stable operation in field applications for trace gas detection. That instrument allowed a MDL of $2.4 \mathrm{pptv}(1 \sigma)$ and $2.7 \mathrm{pptv}(1 \sigma)$ for $\mathrm{NO}_{3}$ and $\mathrm{N}_{2} \mathrm{O}_{5}$, respectively. In a $1 \mathrm{~s}$ interval, the associated uncertainties were estimated to be $19 \%$ for $\mathrm{NO}_{3}$ and $22-36 \%$ for $\mathrm{N}_{2} \mathrm{O}_{5}$, respectively.

\subsubsection{Simultaneous Detection of $\mathrm{HONO}$ and $\mathrm{NO}_{2}$}

A spectral range of 353-387 $\mathrm{nm}$ is communicated for most IBBCEAS set-ups for simultaneous detection of $\mathrm{HONO}$ and $\mathrm{NO}_{2}$. In 2008, Gherman et al. [53] reported the first application of IBBCEAS in the near-UV for the simultaneous detection of $\mathrm{HONO}$ and $\mathrm{NO}_{2}$. The obtained MDL was $\sim 4 \mathrm{ppbv}$ for $\mathrm{HONO}$ and $\sim 14 \mathrm{ppbv}$ for $\mathrm{NO}_{2}$ in a $20 \mathrm{~s}$ acquisition time using a static gas cell set-up with two mirrors $(R \sim 99.85 \%)$ separated by distance of $1.15 \mathrm{~m}$. Moreover, an atmospheric simulation chamber $\left(4 \mathrm{~m}^{3}\right)$ with a cavity length of $4.5 \mathrm{~m}$ was also proposed in this paper. Minimum detection limits of $\sim 0.13 \mathrm{ppbv}$ for $\mathrm{HONO}$ and $\sim 0.38 \mathrm{ppbv}$ for $\mathrm{NO}_{2}$ were achieved in a $10 \mathrm{~min}$ acquisition time. An open-path detection allows one to avoid absorption cell wall losses and sampling induced artifacts. In 2012, Wu et al. [47] demonstrated an experiment for open-path measurements of $\mathrm{HONO}$ and $\mathrm{NO}_{2}$ using a UV LED centered at $365 \mathrm{~nm}$. The cavity length was $\sim 1.85 \mathrm{~m}$ and minimum detection limits were given as $\sim 430$ pptv for $\mathrm{HONO}$ and $\sim 1 \mathrm{ppbv}$ for $\mathrm{NO}_{2}$ in $90 \mathrm{~s}$.

With respect to the IBBCEAS for field application, in 2014, Wu et al. [54], for the first time, demonstrated the feasibility of the simultaneous measurement of ambient $\mathrm{HONO}$ and $\mathrm{NO}_{2}$ concentration levels in a field campaign that are free from chemical and spectral interferences at a 


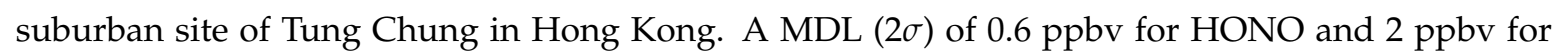
$\mathrm{NO}_{2}$ were achieved with an optimum acquisition time of $120 \mathrm{~s}$. In 2015, Duan et al. [55] reported an IBBCEAS for field measurements in Anhui, China, which was able to detect a HONO concentration level of $0.22 \mathrm{ppbv}$ and $\mathrm{NO}_{2}$ of $0.45 \mathrm{ppbv}(1 \sigma)$ with an acquisition time of $320 \mathrm{~s}$. In order to determine the precision of the IBBCEAS sensor, concentration levels of $\mathrm{HONO}$ and $\mathrm{NO}_{2}$ were recorded for three days, and the results agreed well $\left(R^{2}=0.917\right)$ with those obtained by a commercial DOAS device.

\subsubsection{Simultaneous Detection of $\mathrm{CHOCHO}$ and $\mathrm{NO}_{2}$}

Glyoxal $(\mathrm{CHOCHO})$ is the simplest alpha-dicarbonyl and is present in the atmosphere as a first generation product from VOCs [20] and leads to the formation of secondary organic aerosol (SOA) and ozone $\left(\mathrm{O}_{3}\right)$ [72-74]. Although glyoxal is important in SOA formation and photochemistry, until recently there have been only a few techniques for rapid and in-situ atmospheric glyoxal measurements.

In 2008, Washenfelder et al. [27] reported the first simultaneous measurements of $\mathrm{CHOCHO}$ and $\mathrm{NO}_{2}$ by IBBCEAS. Broadband light generated by a Xe arc lamp was coupled into an optical cavity consisting of two highly-reflective mirrors $(R \sim 99.9966 \%)$ with a separation distance of $94.4 \mathrm{~cm}$. For a 1 min integration time, the measurement precision $( \pm 1 \sigma)$ for $\mathrm{CHOCHO}$ and $\mathrm{NO}_{2}$ were 29 pptv and 20 pptv, respectively. Another important step towards measuring $\mathrm{CHOCHO}$ and $\mathrm{NO}_{2}$ was taken by Fang et al. [20], and a special IBBCEAS instrument was developed by utilizing a custom cage system and a $42 \mathrm{~cm}$-long cavity. This set-up was used for sensitive, real-time, in-situ measurement of $\mathrm{CHOCHO}$ and $\mathrm{NO}_{2}$ in the spectral range of $440-480 \mathrm{~nm}$. A measurement precision of $\mathrm{CHOCHO}$ and $\mathrm{NO}_{2}$ in ambient air was reported to be 28 and $50 \mathrm{pptv}$ at a $60 \mathrm{~s}$ averaging time, and the accuracy was reported to be $5 \%$ and $4 \%$ for the two gas species, respectively. Furthermore, a Kalman adaptive filter method was applied to retrieve gas concentration, leading to a precision improvement of $\mathrm{CHOCHO}$ and $\mathrm{NO}_{2}$ to 8 pptv and 40 pptv in a $21 \mathrm{~s}$ averaging time.

\subsubsection{Simultaneous Detection of $\mathrm{I}_{2}, \mathrm{IO}$ and OIO}

Iodine is an important trace gas species in the earth's atmosphere [75-79]. It can affect atmospheric oxidation capacity in a number of ways, including the catalytic destruction of $\mathrm{O}_{3}$, generating iodine oxides such as IO and OIO and also can lead to the formation of marine aerosol [80-86]. In 2008, Vaughan et al. [26] reported a novel combination of IBBCEAS with a discharge-flow tube for the study of $\mathrm{I}_{2}$, IO and OIO. Light from a $150 \mathrm{~W}$ short-arc Xe lamp was focused into a $145 \mathrm{~cm}$-long cavity, leading to a MDL of $\sim 26 \mathrm{pptv}$ for $\mathrm{I}_{2}$ in a fitting range between $525 \mathrm{~nm}$ and $555 \mathrm{~nm}$, indicating an effective optical path length of $81 \mathrm{~cm}$ in a $60 \mathrm{~s}$ acquisition time. A MDL of $\sim 45 \mathrm{pptv}$ for OIO was achieved in the same fitting range with an effective optical path length of $42.5 \mathrm{~cm}$ in a $5 \mathrm{~s}$ acquisition time. Moreover, a MDL of 210 pptv for IO was obtained between $420 \mathrm{~nm}$ and $460 \mathrm{~nm}$ in $60 \mathrm{~s}$. In 2012, Ashu-Ayem et al. [32] investigated the time profile of $I_{2}$ emissions. In this experiment, the algal specimens were exposed to an atmosphere simulation chamber under controlled conditions. A $75 \mathrm{~W}$ xenon arc lamp and two individual channels including a blue one (420-460 nm) for IO measurement and a green one (520-560 nm) for $\mathrm{I}_{2}$ and OIO detection were used. Two mirrors ( $\left.R \sim 99.97 \%\right)$ with a distance of $199 \mathrm{~cm}$ were adopted to form a cavity. The results showed a good agreement between the fitted spectra and the measured one, which indicated that all significant spectral features can be extracted from the corresponding fitting range. The emission rate varied from $7 \mathrm{pmol} \cdot \mathrm{min}^{-1} \cdot \mathrm{gFW}^{-1}$ to $616 \mathrm{pmol} \cdot \mathrm{min}^{-1} \cdot \mathrm{gFW}^{-1}$ in $\mathrm{O}_{3}$-free air with an average value of $55 \mathrm{pmol} \cdot \mathrm{min}^{-1} \mathrm{gFW}^{-1}$.

\subsection{Single Target Gas Detection}

\subsection{1. $\mathrm{NO}_{3}$}

For $\mathrm{NO}_{3}$ measurement, most IBBCEAS devices are within 640-690 nm using red LEDs. Ball et al. [34] demonstrated the first use of red LED in IBBCEAS, owing to the primary advantage of low-cost, robustness and energy efficiency of the LED [87]. In this paper, the red LED light was 
coupled into a 1.9 m-long optical cavity for $\mathrm{NO}_{3}$ detection. Concentration level of $40.3 \pm 2.5 \mathrm{pptv}$ in ambient air was reported in $516 \mathrm{~s}$, while the root mean square (RMS) of the residual spectrum was stated to be $5.9 \times 10^{-9} \mathrm{~cm}^{-1}$. In 2008, Langridge et al. [56] reported an instrument for the quantitative measurements of $\mathrm{NO}_{3}$. The reported $1 \sigma \mathrm{MDL}$ was $0.25 \mathrm{pptv}$ for a $10 \mathrm{~s}$ acquisition time, which improved with further signal averaging to $0.09 \mathrm{pptv}$ with a $400 \mathrm{~s}$ acquisition time. In 2016, an innovative improvement of the IBBCEAS technique for $\mathrm{NO}_{3}$ detection was reported by Langridge et al. [42]. In this paper, a SC radiation source was firstly used for IBBCEAS technique, which is suitable for its broad wavelength coverage and high spectral brightness. The SC source processes an emission wavelength range from $400 \mathrm{~nm}$ to $2000 \mathrm{~nm}$. By using the optical filter, the effective operating bandwidth of this technique referring to the highly reflective bandwidth of mirrors was limited to $\sim 100 \mathrm{~nm}$. The high-finesse optical cavity was $1.15 \mathrm{~m}$ long formed by two mirrors $(R \sim 99.995 \%)$, leading to a MDL for $\mathrm{NO}_{3}$ of $3 \mathrm{pptv}$ in a $2 \mathrm{~s}$ acquisition time with a corresponding sensitivity of $2.4 \times 10^{-9} \mathrm{~cm}^{-1} \cdot \mathrm{Hz}^{-1 / 2}$ at a $3 \sigma$ noise level. For example, Table 3 describes the $\mathrm{NO}_{3}$ detection performances of the gas sensors implemented with the IBBCEAS technique, including the wavelength range, the effective optical path length, the minimum detection limit as well as the dynamic range.

Table 3. Performances of the IBBCEAS instrument for $\mathrm{NO}_{3}$ detection.

\begin{tabular}{ccccc}
\hline $\begin{array}{c}\text { Wavelength } \\
\text { Range (nm) }\end{array}$ & $\begin{array}{c}\text { Effective Optical } \\
\text { Path Length }(\mathbf{m})\end{array}$ & $\begin{array}{c}\text { Minimum Limit } \\
\text { Detection (pptv) }\end{array}$ & $\begin{array}{c}\text { Dynamic Range } \\
\text { (pptv) }\end{array}$ & Ref. \\
\hline $628-688$ & 2000 & 4 & Not stated & {$[25]$} \\
$630-690$ & 2000 & 2 & Not stated & {$[9]$} \\
$610-640$ & 25,000 & 2 & Not stated & {$[50]$} \\
$638-672$ & 22,000 & 7.9 & $0-185$ & {$[51]$} \\
$645-680$ & 9400 & 1.1 & Not stated & {$[52]$} \\
$640-680$ & 5000 & 2.4 & $0-64$ & {$[44]$} \\
$652-672$ & 38,000 & 2.5 & $0-43$ & {$[34]$} \\
$651-672$ & 11,000 & 0.25 & Not stated & {$[56]$} \\
$640-675$ & 19,200 & 1 & $0-38$ & {$[42]$} \\
\hline
\end{tabular}

\subsection{2. $\mathrm{NO}_{2}$}

The reported IBBCEAS set-ups for $\mathrm{NO}_{2}$ detection are in several spectral range, including $410-490 \mathrm{~nm}, 540-580 \mathrm{~nm}$ and $615-655 \mathrm{~nm}$. For the spectral range of $410-490 \mathrm{~nm}$. In 2006, Langridge et al. [58] developed a portable device for the in-situ measurement of atmospheric $\mathrm{NO}_{2}$. They used a blue LED centered at $455 \mathrm{~nm}$ and a $1.5 \mathrm{~m}$-long high stable optical cavity. Quantitative amounts of ambient $\mathrm{NO}_{2}$ (between $3 \mathrm{ppbv}$ and $32 \mathrm{ppbv}$ ) were retrieved in the presence of ambient aerosol with a statistical uncertainty reaching 100 pptv for a 60 s averaging period. In 2008, Wu et al. [59] demonstrated a set-up based on a $457 \mathrm{~nm}$-LED with a $92.5 \mathrm{~cm}$-long cavity for $\mathrm{NO}_{2}$ detection. The measured $\mathrm{NO}_{2}$ concentration levels ranged from $39.54 \mathrm{ppbv}\left(\mathrm{ng} \cdot \mathrm{mL}^{-1}\right)$ to $53.03 \mathrm{ppbv}\left(\mathrm{ng} \cdot \mathrm{mL}^{-1}\right)$, with an uncertainty ranging from $3.1 \mathrm{ppbv}\left(\mathrm{ng} \cdot \mathrm{mL}^{-1}\right)$ to $4.7 \mathrm{ppbv}\left(\mathrm{ng} \cdot \mathrm{mL}^{-1}\right)$ during a sampling period of $80 \mathrm{~s}$. In 2009, $\mathrm{Wu}$ et al. [60] introduced Allan variance plot into IBBCEAS to optimize averaging time for SNR enhancement. A MDL of $\sim 2.2 \mathrm{ppbv}(1 \sigma)$ for $\mathrm{NO}_{2}$ was achieved at an optimal averaging time of $100 \mathrm{~s}$. In 2011, a three channel-based IBBCEAS set-up was reported by Kennedy et al. [52]. The third channel is used for $\mathrm{NO}_{2}$ detection using a blue LED centered at $460 \mathrm{~nm}$. The Allan deviation indicated a MDL of 5 pptv for $\mathrm{NO}_{2}$ in an averaging time of $1748 \mathrm{~s}$ at a pressure of 1 bar. In 2013, Ling et al. [61] used a blue LED centered at $462 \mathrm{~nm}$ with a $70 \mathrm{~cm}$-long optical cavity $(R \sim 99.9 \%)$. Atmospheric $\mathrm{NO}_{2}$ concentration levels ( 1 to $35 \mathrm{ppbv}$ ) during a seven-day period were retrieved from the absorption spectra between $444 \mathrm{~nm}$ and $468 \mathrm{~nm}$. The results are in a good agreement $\left(R^{2}=0.975\right)$ with a commercial long path-differential optical absorption spectroscopy (LP-DOAS) device [88].

In order to avoid the effect of calibration errors of the mirror reflectivity on the quantitative result retrieved by traditional method, Ling et al. [45] presented a new retrieval method based on the measurement of atmospheric $\mathrm{O}_{2}-\mathrm{O}_{2}$ absorption. Experimental results showed that this method can be 
used to quantify multiple gas species using IBBCEAS, with the result insensitive to the calibration error of mirror reflectivity. In 2017, Liang et al. [62] presented an IBBCEAS set-up on the airplane to observe the actual atmospheric $\mathrm{NO}_{2}$ spatial distribution. The optical cavity fabricated by the Perfluoroalkoxy alkane (PFA) material for reducing wall losses, was formed by two high-reflectivity mirrors $(R>0.9999$ $@ 440-450 \mathrm{~nm}$ ) separated by a distance of $1 \mathrm{~m}$. The IBBCEAS system was deployed on an airborne platform, leading to a $\mathrm{NO}_{2}$ MDL of 95 pptv $(1 \sigma)$ with a time resolution of $2 \mathrm{~s}$.

For the spectral range of $540-580 \mathrm{~nm}$, in 2004, Ball et al. [34] demonstrated the first use of a green LED $(535 \mathrm{~nm})$ in IBBCEAS. The green LED light was coupled into a $1.5 \mathrm{~m}$-long cavity. This set-up allows for a real time measurement of $\mathrm{NO}_{2}$ concentration levels of $64.8 \pm 0.7 \mathrm{ppbv}$ in an optimal acquisition time of $500 \mathrm{~s}$. With respect to the spectral range of 615-655 nm, in 2008, Triki et al. [57] demonstrated a set-up based on a $643 \mathrm{~nm}$-LED for $\mathrm{NO}_{2}$ detection. A $50 \mathrm{~cm}$-long cavity was formed by two high-reflectivity mirrors $(R \sim 99.92 \%)$. A MDL of $<10 \mathrm{ppbv}$ was communicated in a $1 \mathrm{~s}$ averaging time.

\subsubsection{HONO}

For HONO measurement, the reported IBBCEAS device is in a spectral range of 360-375 nm using UV LED. In 2017, Nakashima et al. [63] reported an IBBCEAS set-up based on a UV-LED for HONO detection, with a $50 \mathrm{~cm}$-long cavity formed by two mirrors ( $R \sim 99.985 \%)$. A MDL of $0.2 \mathrm{ppbv}$ for HONO was achieved in a $5 \mathrm{~min}$ acquisition time. In addition, good agreement $\left(R^{2}=0.94\right)$ was found between IBBCEAS and a commercial analyzer for the measurement of HONO.

\subsection{4. $\mathrm{I}_{2}$}

In 2004, Ball et al. [34] developed an IBBCEAS instrument for the in situ measurement of atmospheric $\mathrm{I}_{2}$ using a green LED centered at $535 \mathrm{~nm}$. Quantitative concentration levels of $\mathrm{I}_{2}$ of $991 \pm 11$ pptv were retrieved in a fitting range between $530 \mathrm{~nm}$ and $565 \mathrm{~nm}$, and the RMS value of the residual spectra was $5.2 \times 10^{-9} \mathrm{~cm}^{-1}$ for a $300 \mathrm{~s}$ averaging period. In 2014, Johansson et al. [64] demonstrated the application of an IBBCEAS to the detection of $\mathrm{I}_{2}$ at ambient pressure. The acquisition range was in the green spectral region around $500-550 \mathrm{~nm}$ using two mirrors with a reflectivity of $\sim 99.99 \%$ and a distance of $0.5 \mathrm{~m}$. A MDL of $0.04 \mathrm{nmol} / \mathrm{L}$ ( 1 ppbv) without aerosols and $0.4 \mathrm{nmol} / \mathrm{L}$ $(\sim 10 \mathrm{ppbv})$ in the presence of aerosols were communicated.

\subsubsection{Industrial Pollutants Measurement $\left(\mathrm{C}_{4} \mathrm{H}_{6}, \mathrm{C}_{4} \mathrm{H}_{8} \mathrm{O}_{2}\right)$}

1,3-butadiene $\left(\mathrm{C}_{4} \mathrm{H}_{6}\right)$ is an industrially produced synthetic rubber and plastics and a harmful air pollutant. Furthermore, $\mathrm{C}_{4} \mathrm{H}_{6}$ can cause breathing problems and is a human carcinogen. Denzer et al. [35] developed an instrument by employing a near-IR SLED. Two types of detection schemes, including a dispersive monochromator with a lock-in and a Fourier transform interferometer, were demonstrated and compared with each other. The minimum detectable absorption coefficient were obtained to be $6.1 \times 10^{-8} \mathrm{~cm}^{-1}$ using the dispersive spectrometer with the help of phase-sensitive detection and $1.5 \times 10^{-8} \mathrm{~cm}^{-1}$ using the Fourier transform interferometer.

1,4-Dioxane $\left(\mathrm{C}_{4} \mathrm{H}_{8} \mathrm{O}_{2}\right)$, one of the significant cyclic ethers with trace levels in the troposphere, are widely used in the field of biological, chemistry and textile. $\mathrm{C}_{4} \mathrm{H}_{8} \mathrm{O}_{2}$ is not biodegradable and was classified as a potential carcinogen by the US Environmental Protection Agency (EPA). Widely used as an industrial solvent, $\mathrm{C}_{4} \mathrm{H}_{8} \mathrm{O}_{2}$ is considered as the major anthropogenic source of 1,4-dioxane in the atmosphere [89,90]. Chandran et al. [65] reported a novel FT-IBBCEAS to record the absorption of $\mathrm{C}_{4} \mathrm{H}_{8} \mathrm{O}_{2}$ in the spectral range of $5900-8230 \mathrm{~cm}^{-1}$ with a resolution of $0.08 \mathrm{~cm}^{-1}$. Light from a SC source was coupled into a $644 \mathrm{~cm}$-long optical cavity, leading to a MDL represented by an absorption coefficient of $8 \times 10^{-8} \mathrm{~cm}^{-1}(\sim 200 \mathrm{pptv})$ with an averaging time of $120 \mathrm{~min}$. 


\subsection{6. $\mathrm{CO}_{2}, \mathrm{CH}_{4}, \mathrm{C}_{2} \mathrm{H}_{2}$ Measurement}

Almost all molecules exhibit strong absorption in the IR region due to fundamental vibrational-rotational transitions with specific molecular markers, which are capable of sensitive detection of many important atmospheric IR trace gas species using absorption spectroscopy [33]. In 2011, Denzer et al. [36] combined a SC source and a SLED with FT-IBBCEAS for spectroscopic and kinetic study of $\mathrm{C}_{2} \mathrm{H}_{2}$ and $\mathrm{CO}_{2}$. The established optical cavity consisted of two mirrors with a reflectivity of $\sim 99.98 \%$ and a separation distance of $25 \mathrm{~cm}$. Compared to SLED, a high detection sensitivity was achieved using the SC source, with a minimum detectable absorption coefficient of $\sim 4 \times 10^{-9} \mathrm{~cm}^{-1}$ at an acquisition time of $4 \mathrm{~min}$.

In 2015, another innovative improvement of IBBCEAS technique, was reported by Aalto et al. [91], which allowed the sensing of $\mathrm{CO}_{2}$ and $\mathrm{CH}_{4}$ in the 1590-1700 nm. A tailored SC source was used with a $1.17 \mathrm{~m}$-long cavity consisting of two mirrors ( $R \sim 99.99 \%)$. A SLED was used in their set-up in order to perform a systematic comparison between the performance of a SC source and that of a SLED. A minimum detectable absorption coefficient $(3 \sigma)$ of $2.2 \times 10^{-9} \mathrm{~cm}^{-1}$ and $6.2 \times 10^{-9} \mathrm{~cm}^{-1}$ were achieved with the use of a SC and SLED source, respectively. In 2017, Amiot et al. [92], for the first time, presented the use of all-fiber SC source combined with IBBCEAS in the mid-IR wavelength range from $3000 \mathrm{~nm}$ to $3450 \mathrm{~nm}$. A $1 \mathrm{~m}$-long high-finesse optical cavity was formed by two mirrors $(R \sim 99.95 \%)$, and good agreement was found between the measured and modelled absorption using the nominal concentrations with a sub parts-per-million in volume (ppmv) accuracy for $\mathrm{CH}_{4}$ and $\mathrm{C}_{2} \mathrm{H}_{2}$ detection, proving the feasibility of this sensing technique.

\subsection{7. $\mathrm{H}_{2} \mathrm{O}$ Measurement}

The IBBCEAS technique also found applications in the field of spectroscopic investigation in a high temperature environment. In 2009, Watt et al. [93] demonstrated the combination of IBBCEAS with SC radiation for the measurement of the flame-generated $\mathrm{H}_{2} \mathrm{O}$ in the $1500 \mathrm{~nm}$ to $1550 \mathrm{~nm}$ region. Weak absorption lines of $\mathrm{H}_{2} \mathrm{O}$ at high temperature were observed in an acquisition time of $\sim 30 \mathrm{~min}$, which was hard to observe in a direct absorption measurement. The results demonstrated the efficiency of IBBCEAS for spectroscopic research in electrical and plasma discharges, or in flames at high temperature under a steady state.

Since the strong, narrow absorption lines of $\mathrm{H}_{2} \mathrm{O}$ are under-resolved and hence exhibit non-Beer-Lambert law behavior at the resolution encountered in IBBCEAS experiments, a new treatment was proposed by Langridge et al. [56], by calculating the effective absorption cross sections for fitting the differential structure in IBBCEAS spectra. The ring-down time of the cavity, the concentration of the absorber and the detailed spectroscopy of the absorber over the narrow range of wavelengths sampled onto the CCD detector pixel are all considered in the calculation of the effective absorption cross sections. This approach was tested on the IBBCEAS spectra of water vapor's $4 v+\delta$ absorption bands around $650 \mathrm{~nm}$, and the retrieved water amounts agreed well with the measurement results of the relative humidity from a commercial hygrometer. Furthermore, Aalto et al. [91] reported a DOAS-type fitting method for data analysis that properly account for the combined effect of absorption line saturation and limited spectral resolution. In this model, the single-pass gas absorption was given by a linear approximation of Beer-Lambert law and the measured transmittance in the presence of a gas sample was convolved with the instrument slit function since it directly affected the transmittance spectrum. In contrast to previous approaches, this method is able to cope with a wide range of strong and weak absorption features typically of multi-component measurements, leading to a greatly enhanced dynamic range. 


\section{Target Gas Species in Field Measurement}

In order to validate the performance of the developed IBBCEAS instrument, a large variety of measurements were performed under ambient conditions. High-power LEDs are compact, power efficient, inexpensive, stable in photon fluence and have a long life $(>10,000 \mathrm{~h})$, which makes them suitable for an IBBCEAS system in field measurements. As shown in Table 4, most of the target gas species in field IBBCEAS measurements are nitrogen oxides and nitrous acid $\left(\mathrm{NO}_{2}, \mathrm{NO}_{3}, \mathrm{~N}_{2} \mathrm{O}_{5}\right.$, HONO). Several platforms are demonstrated for field measurements, including marine boundary layer, aircraft, urban environment and suburban site. The measurement time varied from $1 \mathrm{~h}$ to 21 days, resulting in different concentration levels between several pptv and tens of ppbv. Temporal resolution is defined as the acquisition time of a single spectra of the target gas [54,62]. The measured concentration range refers to the concentration level ranges observed during the field measurements where the reported sensors were used. In order to verify the accuracy of the results acquired by the IBBCEAS set-ups, their performance was also compared with the commercial analytical instruments. 
Table 4. Performances of the reported IBBCEAS for target gas species in field measurements. * the correlation between IBBCEAS set-up and the commercially analytical instrument.

\begin{tabular}{|c|c|c|c|c|c|c|c|c|c|c|c|}
\hline $\begin{array}{l}\text { Different } \\
\text { Platforms }\end{array}$ & Light Source & Gas & Location & Date & Duration & $\begin{array}{c}\text { Average } \\
\text { Concentration }\end{array}$ & $\begin{array}{c}\text { Measured } \\
\text { Concentration } \\
\text { Range }\end{array}$ & $\begin{array}{c}\text { Minimum Detection } \\
\text { Limit }\end{array}$ & $\begin{array}{c}\text { Temporal } \\
\text { Resolution }\end{array}$ & $R^{2 *}$ & Ref. \\
\hline $\begin{array}{c}\text { Marine } \\
\text { boundary } \\
\text { layer }\end{array}$ & Red-LED & $\begin{array}{c}\mathrm{NO}_{2}, \mathrm{NO}_{3}, \\
\mathrm{~N}_{2} \mathrm{O}_{5}\end{array}$ & Brittany, France & September 2006 & $15 \mathrm{~h}$ & Not stated & $\mathrm{NO}_{3}$ (above 1 ppbv) & $\mathrm{NO}_{3}(0.25$ pptv $)$ & $10 \mathrm{~s}$ & Not stated & [56] \\
\hline \multirow[t]{2}{*}{ Aircraft } & Red-LED & $\begin{array}{c}\mathrm{NO}_{2}, \mathrm{NO}_{3}, \\
\mathrm{~N}_{2} \mathrm{O}_{5}\end{array}$ & $\begin{array}{l}\text { North Sea and } \\
\text { Thames Estuary, } \\
\text { UK }\end{array}$ & July 2010 & $5 \mathrm{~h}$ & Not stated & $\begin{array}{c}\mathrm{NO}_{3}(<2-200 \mathrm{pptv}) \\
\mathrm{N}_{2} \mathrm{O}_{5}(<2-600 \mathrm{pptv}) \\
\mathrm{NO}_{2}(<0.05-12 \text { ppbv }) \\
\end{array}$ & $\begin{array}{c}\mathrm{NO}_{3} \text { (1.1pptv) } \\
\mathrm{N}_{2} \mathrm{O}_{5} \text { (2.4 pptv) } \\
\mathrm{NO}_{2} \text { (5 pptv) }\end{array}$ & $\begin{array}{l}\mathrm{NO}_{3}(1.2 \mathrm{~s}) \\
\mathrm{N}_{2} \mathrm{O}_{5}(8 \mathrm{~s}) \\
\mathrm{NO}_{2}(1 \mathrm{~s})\end{array}$ & 0.99 & [52] \\
\hline & Blue-LED & $\mathrm{NO}_{2}$ & Anhui, China & March 2016 & $36 \mathrm{~h}$ & $\sim 11.98 \mathrm{ppbv}$ & 4-31 ppbv & $\mathrm{NO}_{2}(95 \mathrm{pptv})$ & $2 \mathrm{~s}$ & 0.86 & [62] \\
\hline \multirow{5}{*}{ Urban site } & Red-LED & $\mathrm{NO}_{3}, \mathrm{~N}_{2} \mathrm{O}_{5}$ & Beijing, China & $\begin{array}{l}\text { February, } \\
\text { May } 2016\end{array}$ & 7 days & Not stated & $\begin{array}{l}\mathrm{NO}_{3}+\mathrm{N}_{2} \mathrm{O}_{5}(1 \mathrm{ppbv}) \\
\mathrm{NO}_{3} \text { (up to } 50 \text { pptv) }\end{array}$ & $\begin{array}{l}\mathrm{NO}_{3}(2.4 \text { pptv) } \\
\mathrm{N}_{2} \mathrm{O}_{5}(2.7 \mathrm{pptv})\end{array}$ & $1 \mathrm{~s}$ & Not stated & [44] \\
\hline & Blue-LED & $\mathrm{NO}_{2}$ & Cambridge, UK & October 2006 & $38 \mathrm{~h}$ & Not stated & 3-34 ppbv & $\mathrm{NO}_{2}(100 \mathrm{pptv})$ & $60 \mathrm{~s}$ & 0.9982 & [58] \\
\hline & Blue-LED & $\mathrm{NO}_{2}$ & Anhui, China & May 2012 & 7 days & Not stated & $1-35 \mathrm{ppbv}$ & $\mathrm{NO}_{2}(9.6 \mathrm{ppbv})$ & $90 \mathrm{~s}$ & 0.983 & [61] \\
\hline & UV-LED & $\begin{array}{l}\mathrm{HONO}, \\
\mathrm{NO}_{2}\end{array}$ & Anhui, China & March 2014 & 3 days & $\begin{array}{c}\mathrm{HONO} \\
(0.68 \mathrm{ppbv}) \\
\mathrm{NO}_{2}(14 \mathrm{ppbv})\end{array}$ & $\begin{array}{c}\text { HONO } \\
(<0.22-3.49 \mathrm{ppbv}) \\
\mathrm{NO}_{2}(2.86-51.6 \mathrm{ppbv})\end{array}$ & $\begin{array}{l}\mathrm{HONO}(0.22 \mathrm{ppbv}) \\
\mathrm{NO}_{2}(0.45 \mathrm{ppbv})\end{array}$ & $20 \mathrm{~min}$ & $\begin{array}{l}\mathrm{HONO}(0.917) \\
\mathrm{NO}_{2}(0.937)\end{array}$ & [55] \\
\hline & UV-LED & HONO & Tokyo, Japan & January 2016 & 21days & $1.5 \pm 1.1 \mathrm{ppbv}$ & $0.2-7.1 \mathrm{ppbv}$ & HONO (0.2 ppbv) & $20 \mathrm{~min}$ & 0.94 & [63] \\
\hline \multirow{2}{*}{ Suburban site } & UV-LED & $\begin{array}{l}\mathrm{HONO}, \\
\mathrm{NO}_{2}\end{array}$ & $\begin{array}{l}\text { Tung Chung, } \\
\text { Hong Kong }\end{array}$ & May 2012 & 2 days & Not stated & $\begin{array}{l}\text { HONO (up } \\
\text { to } \sim 2 \text { ppbv) }\end{array}$ & HONO (0.3 ppbv) & $2 \min$ & HONO (0.7) & [54] \\
\hline & Blue-LED & $\begin{array}{l}\mathrm{NO}_{2,} \\
\text { CHOCHO }\end{array}$ & $\begin{array}{l}\text { PRD and YRD } \\
\text { regions, China }\end{array}$ & August 2017 & 3 days & Not stated & $\begin{array}{c}\mathrm{NO}_{2}(2-15 \mathrm{ppbv}) \\
\text { CHOCHO } \\
(<28-180 \mathrm{pptv})\end{array}$ & $\begin{array}{c}\mathrm{NO}_{2}(40 \mathrm{pptv}) \\
\text { CHOCHO (8 pptv) }\end{array}$ & $21 \mathrm{~s}$ & Not stated & [20] \\
\hline
\end{tabular}




\subsection{Marine Boundary Layer Measurement}

For better understanding the atmospheric chemistry of reactive trace gases such as $\mathrm{NO}_{3}$ and $\mathrm{N}_{2} \mathrm{O}_{5}$ in the marine boundary layer, Langridge et al. [56] reported the performance of a red LED-based IBBCEAS system for field operation in the marine boundary layer in summer 2006. In this experiment, the mixture of $\mathrm{NO}_{3}$ and $\mathrm{N}_{2} \mathrm{O}_{5}$ made during the RHaMBLe field campaign was measured at Roscoff on the northern coast of Brittany, France. The IBBCEAS instrument was housed in a shipping container on the quayside in front of the station. $\mathrm{NO}_{3}$ is produced in the atmosphere by the reaction between $\mathrm{NO}_{2}$ and $\mathrm{O}_{3}$ and is photolyzed in sunlight. The concentration of $\mathrm{NO}_{3}$ and $\mathrm{N}_{2} \mathrm{O}_{5}$ was found to increase after sunset and decrease again at night.

\subsection{Airborne Measurement}

In order to obtain the concentration variation of the gas species in the tropospheric atmosphere, airborne experiments have been carried. In 2011, Kennedy et al. [52], for the first time, developed an IBBCEAS instrument for airborne usage with three separate optical channels. This instrument offers a capability of in-situ measurement of $\mathrm{NO}_{3}, \mathrm{~N}_{2} \mathrm{O}_{5}$ and $\mathrm{NO}_{2}$ in the "RONOCO" campaign. During the flight, concentration levels of $\mathrm{NO}_{3}$ and $\mathrm{N}_{2} \mathrm{O}_{5}$ changed from below 2 pptv up to 200 pptv and 600 pptv, respectively. Concentration levels of $\mathrm{NO}_{2}$ varied from below 50 pptv up to 12 ppbv in the polluted zones. Compared to the IBBCEAS data in this flight with a photolytic chemiluminescence-based detector, a strong correlation $\left(R^{2}=0.99\right)$ was achieved, demonstrating the high reliability of the IBBCEAS instrument in airborne deployment. In 2016, Liang et al. [62] measured $\mathrm{NO}_{2}$ in Anhui, China. The $\mathrm{NO}_{2}$ concentration value varied from $4 \mathrm{ppbv}$ to $31 \mathrm{ppbv}$ with an average value of 11.98 ppbv. Furthermore, they carried out an airborne $\mathrm{NO}_{2}$ measurement in Hebei province, China. The concentration levels were $\sim 10.6 \mathrm{ppbv}$ on the ground, and dropped sharply to $\sim 2$ ppbv at an altitude of $700 \mathrm{~m}$. Subsequently, the $\mathrm{NO}_{2}$ concentration decreased to below the MDL of 95 pptv with the further increment of flight altitude. By using the airborne observation, the profile informatio of $\mathrm{NO}_{2}$ over the tropospheric atmosphere of Shijiazhuang and other areas in North China was obtained.

\subsection{Urban Environment Measurement}

Due to the active human activities and environmental pollution, ambient gas observations at urban sites are very important. With a blue LED-based IBBCEAS, Langridge et al. [58] measured the $\mathrm{NO}_{2}$ concentration levels in ambient air in October 2006. During the 38 h' measurement, $\mathrm{NO}_{2}$ concentration levels varied from $3 \mathrm{ppbv}$ to $34 \mathrm{ppbv}$, and compared with those obtained with a commercial chemiluminescence detector, a high correlation with an $R^{2}$ coefficient of 0.998 was reported. In 2012, Ling et al. [61] measured atmospheric $\mathrm{NO}_{2}$ concentration levels with their IBBCEAS instrument. During seven-day's measurements in May 2012, $\mathrm{NO}_{2}$ concentration levels varied from 1 ppbv to 35 ppbv. In order to verify the accuracy of the IBBCEAS set-up, a LP-DOAS device was used to measure atmospheric $\mathrm{NO}_{2}$. A correlation $\left(R^{2}\right)$ of 0.983 indicates the good agreement between the IBBCEAS and LP-DOAS device. In 2014, Duan et al. [55] recorded HONO and $\mathrm{NO}_{2}$ concentration levels for three days with their IBBCEAS instrument. The HONO concentration varied from below the MDL to $3.49 \mathrm{ppbv}$ with an averaging value of $0.68 \mathrm{ppbv}$ and the $\mathrm{NO}_{2}$ concentration ranged from $2.86 \mathrm{ppbv}$ to $51.6 \mathrm{ppbv}$ with an average value of $14 \mathrm{ppbv}$. In addition, the results obtained by the IBBCEAS set-up were compared with a DOAS set-up. The linear correlation coefficient of $\mathrm{NO}_{2} \mathrm{was}$ $0.937\left(R^{2}=0.937\right)$, and the value of HONO was $0.917\left(R^{2}=0.917\right)$. The obtained correlation verified the accuracy of the IBBCEAS technique for simultaneous measurement of atmospheric $\mathrm{HONO}$ and $\mathrm{NO}_{2}$ concentration levels.

In 2016, Wang et al. [44] successfully carried out two comprehensive field campaigns in the winter and summer in Beijing. The used instrument was capable of measuring $\mathrm{NO}_{3}$ and $\mathrm{N}_{2} \mathrm{O}_{5}$ in one channel simultaneously. In these two campaigns, up to 1 ppbv of $\mathrm{NO}_{3}$ and $\mathrm{N}_{2} \mathrm{O}_{5}$ was observed with the presence of high aerosol compositions. In the summer campaign, up to 50 pptv of $\mathrm{NO}_{3}$ was present 
at night, which indicates active chemistry at night in Beijing. In the same year, Nakashima et al. [94] recorded numerous trace gas species in winter in Tokyo including $\mathrm{SO}_{2}, \mathrm{O}_{3}, \mathrm{NO}, \mathrm{NO}_{2}$ and $\mathrm{HONO}$. The HONO concentration levels ranged from less than the MDL of $0.2 \mathrm{ppbv}$ to $7.1 \mathrm{ppbv}$, which changed similarly to the $\mathrm{NO}_{2}$ and $\mathrm{NO}$ concentrations. At the same time, the ratio of $\mathrm{HONO}$ to $\mathrm{NO}_{2}$ was also recorded. The variation trend was the same as that of $\mathrm{HONO}$, with a range of the ratio from 0.002 to 0.19. Moreover, during the 21-day measurement period, it was found that the concentration levels were higher during the night than during the day. This is because photolysis occurs during the day and the height of the boundary layer is lower during the winter night. In addition, the $\mathrm{NO}_{2}$ concentration levels measured by IBBCEAS agreed well $\left(R^{2}=0.94\right)$ with that obtained by the cavity attenuated phase-shift spectroscopy (CAPS)- $\mathrm{NO}_{2}$ analyzer [94].

\subsection{Suburban Site Measurement}

With respect to the trace gas sensing in the field campaign at a suburban site, for the first time, a UV LED-based IBBCEAS device was developed by Wu et al. [54] for simultaneous measurements of $\mathrm{HONO}$ and $\mathrm{NO}_{2}$ in 2012. Field intercomparison campaign at a suburban site of Tung Chung in Hong Kong was performed and daytime and nighttime concentration levels of $\mathrm{HONO}$ and $\mathrm{NO}_{2}$ were recorded. Atmospheric HONO concentration levels of up to $\sim 2$ ppbv were obtained during the observation period. And the observed $\mathrm{HONO}$ to $\mathrm{NO}_{2}$ ratios (varying between $\sim 0$ and 0.45 ) indicate a very complex nocturnal environment for HONO formation at Tung Chung. A correlation $\left(R^{2}=0.7\right)$ of HONO concentration between the IBBCEAS and the LOPAP device was achieved, together with the correlation of $\mathrm{NO}_{2}$ concentration measurements of $R^{2}=0.82$ between the IBBCEAS and a commercial $\mathrm{NO}_{2}$ analyzer.

In 2017, Fang et al. [20] firstly reported the development of a cage-based IBBCEAS instrument for ambient measurements of $\mathrm{NO}_{2}$ and $\mathrm{CHOCHO}$ in China's Pearl River Delta (PRD) and Yangtze River Delta (YRD) regions. During these measurements, concentration levels of $\mathrm{NO}_{2}$ and $\mathrm{CHOCHO}$ changed from 2 ppbv to $15 \mathrm{ppbv}$ and below $28 \mathrm{pptv}$ up to $\sim 180 \mathrm{pptv}$, respectively. Moreover, the Kalman adaptive filtering technique was applied to IBBCEAS based measurement, which efficiently reduced the real-time noise and improved the retrieval accuracy without affecting the time resolution.

\section{Outlook}

The development of the IBBCEAS technique was significant in recent years, and further improvements of the IBBCEAS are expected, including a higher detection sensitivity, a wider spectral coverage, an improved spectral resolution and the potential for sensor system integration.

(1) Sensitivity. There are a number of improvements of the IBBCEAS technique that can lead to higher detection sensitivity. First, the optical throughput and the sensitivity can be improved by using new developed SC radiation sources, owing to their combination of high spectral brightness and broadband wavelength coverage $[95,96]$. The application of LED in IBBCEAS will become more extensive with the increase of the intensity and stability of LED. Second, the SNR can be improved by suppressing the optical feedback using an optical isolator or energy-efficient spectral filters. In addition, the minimum detection limit can be enhanced by employing high-finesse cavities as well as optimizing coupling parameters. Furthermore, the accuracy and sensitivity can also be improved by using high-order correction parameters in the calibration of the mirror reflectivity [91].

(2) Spectral coverage. In order to increase the spectral bandwidth, the spectral range of the mirror with high reflectivity should be expanded through further progress in optical fabrication technology. The use of uncoated reflective optics (such as prisms $[97,98]$ ) is an advancement which enables the use of cavities over a large spectral range. Furthermore, the use of SC radiation source is a recent advancement for access to a wide spectral range from the UV [99] to the mid-IR [100]. The supercontinuum radiation source which outperforms conventional thermal sources in terms of brightness and collimation is of particular interest for trace gas sensing where strong mid-IR absorption bands associated with fundamental vibrational transitions can be measured [91]. Further 
improvements of output powers and spectral flux stability of SC light sources enable the application of mid-IR absorption spectroscopy without the use of expensive mid-IR lasers (e.g., quantum cascade laser, interband cascade laser) [101].

(3) Spectral resolution. The spectral resolution could be improved in a variety of ways. By replacing a scanning spectrum analyzer with a detector array, the spectral acquisition time can be reduced, leading to a high temporal resolution and an increased sensitivity [93] In addition, this improvement will also decrease the sensor cost and make it more compact [91] Secondly, the FT-IBBCEAS can be used to record the absorption property of a gas molecular over a broad spectral region with sufficiently high resolution. This technique is helpful to identify weak absorption of specific gaseous species, together with many other useful applications, including spectral studies of isotopic samples, flames, plasma discharges or detection of chemical sources [65].

(4) System miniaturization and integration. Due to conceptual simplicity and robustness, the IBBCEAS technique is ideally suitable for trace gas sensing applications. The future of this technique will focus on developing portable instrumentation which is capable of multiple gas species detection with high sensitivity, wide bandwidth, optimal spectral resolution as well as high temporal resolution.

\section{Conclusions}

Due to experimental simplicity, high sensitivity and high temporal resolution, the IBBCEAS technique has been an important topic in the field of absorption spectroscopy. IBBCEAS can be described as the combination of CEAS and DOAS, leading to unique advantages of compactness and robustness with short integration time (seconds to minutes) as well as multiple gas species analysis. In this review, we addressed the facts about the principle and evolution of the IBBCEAS technique together with the achievement of the application of this technique in trace gas sensing. Due to a broad spectral range, the IBBCEAS technique is suitable for the proof-of-principle measurement of weak atmospheric transition and overtone bands of gas molecules, and also for the detection of many atmospheric trace gas species (e.g., $\mathrm{NO}_{2}, \mathrm{NO}_{3}, \mathrm{HONO}, \mathrm{CO}_{2}$ ). Field measurements using IBBCEAS under ambient conditions were also discussed. The advances of IBBCEAS technique opens up new research paths for observing the spatial and long-term trends of atmospheric changes. The technique will further improve our vision and understanding of the tropospheric processes and trends, which will have a significant effect on predicting the atmospheric changes in the future.

Author Contributions: Resources, Y.W. and Y.Z.; Writing-Original Draft Preparation, K.Z. and C.Z.; Writing-Review \& Editing, C.Z. and F.K.T.; Supervision, Y.W.; Funding Acquisition, C.Z. and Y.W.

Funding: This research was funded by the National Key R\&D Program of China (No. 2017YFB0405300), National Natural Science Foundation of China (Nos. 61775079, 61627823), Key Science and Technology R\&D program of Jilin Province, China (No. 20180201046GX), Industrial Innovation Program of Jilin Province, China (No. 2017C027), and the National Science Foundation (NSF) ERC MIRTHE award and Robert Welch Foundation (No. C0586).

Conflicts of Interest: The authors declare no conflict of interest.

\section{References}

1. Russell, J.M.; Gordley, L.L.; Park, H.J.; Drayson, S.R.; Hesketh, W.D.; Cicerone, R.J.; Tuck, A.F.; Frederick, J.E.; Harries, J.E.; Crutzen, P.J. The halogen occultation experiment. J. Geophys. Res. 1993, 98, 10777-10797. [CrossRef]

2. Anthony, K.W.; Daanen, R.; Anthony, P.; Deimling, T.S.V.; Ping, C.L.; Chanton, J P.; Grosse, G. Methane emissions proportional to permafrost carbon thawed in Arctic lakes since the 1950s. Nat. Geosci. 2016, 9, 679-682. [CrossRef]

3. Miller, C.E.; Brown, L.R.; Toth, R.A. Spectroscopic challenges for high accuracy retrievals of atmospheric $\mathrm{CO}$ and the Orbiting Carbon Observatory (OCO) experiment. Comptes Rendus Physique 2005, 6, 876-887. [CrossRef]

4. Cygan, A.; Wcislo, P.; Wójtewicz, S.; Maslowski, P.; Domyslawska, J.; Trawinski, R.S.; Ciurylo, R.; Lisak, D. Precise cavity enhanced absorption spectroscopy. J. Phys. Conf. Ser. 2014, 548, 012015. [CrossRef] 
5. O'Keefe, A.; Deacon, D.A.G. Cavity ring-down optical spectrometer for absorption measurements using pulsed laser sources. Rev. Sci. Instrum. 1988, 59, 2544-2551. [CrossRef]

6. Brown, S.S.; Stark, H.; Ciciora, S.J.; Mclaughlin, R.J.; Ravishankara, A.R. Simultaneous in-situ detection of atmospheric $\mathrm{NO}_{3}$ and $\mathrm{N}_{2} \mathrm{O}_{5}$ via cavity ring-down spectroscopy. Geophys. Res. Lett. 2001, 28, 3227-3230. [CrossRef]

7. Awtry, A.R.; Miller, J.H. Development of a cw-laser-based cavity-ringdown sensor aboard a spacecraft for trace air constituents. Appl. Phys. B 2002, 75, 255-260. [CrossRef] [PubMed]

8. Ayers, J.D.; Apodaca, R.L.; Simpson, W.R.; Baer, D.S. Off-axis cavity ringdown spectroscopy: Application to atmospheric nitrate radical detection. Appl. Opt. 2005, 44, 7239-7242. [CrossRef] [PubMed]

9. Varma, R.M.; Venables, D.S.; Ruth, A.A.; Heitmann, U.; Schlosser, E.; Dixneuf, S. Long optical cavities for open-path monitoring of atmospheric trace gases and aerosol extinction. Appl. Opt. 2009, 48, 159-171. [CrossRef]

10. Walsh, A.; Zhao, D.; Ubachs, W.; Linnartz, H. Optomechanical shutter modulated broad-band cavity-enhanced absorption spectroscopy of molecular transients of astrophysical interest. J. Phys. Chem. A 2013, 117, 9363-9369. [CrossRef] [PubMed]

11. Engeln, R.; Berden, G.; Peeters, R.; Meijer, G. Cavity enhanced absorption and cavity enhanced magnetic rotation spectroscopy. Rev. Sci. Instrum. 1998, 69, 3763-3769. [CrossRef]

12. Fiedler, S.E.; Hese, A.; Ruth, A.A. Incoherent broad-band cavity-enhanced absorption spectroscopy. Chem. Phys. Lett. 2003, 371, 284-294. [CrossRef]

13. Platt, U. Modern methods of the measurement of atmospheric trace gases invited lecture. Phys. Chem. Chem. Phys. 1999, 1, 5409-5415. [CrossRef]

14. Platt, U.; Perner, D. Direct measurements of atmospheric $\mathrm{CH}_{2} \mathrm{O}, \mathrm{HNO}_{2}, \mathrm{O}_{3}, \mathrm{NO}_{2}, \mathrm{SO}_{2}$ by differential optical absorption in the near UV. J. Geophys. Res. Oceans 1980, 85, 7453-7458. [CrossRef]

15. Zybin, A.; Kuritsyn, Y.A.; Mironenko, V.R.; Niemax, K. Cavity enhanced wavelength modulation spectrometry for application in chemical analysis. Appl. Phys. B 2004, 78, 103-109. [CrossRef]

16. O'Keefe, A. Integrated cavity output analysis of ultra-weak absorption. Chem. Phys. Lett. 1998, 293, 331-336. [CrossRef]

17. Fiedler, S.E.; Hese, A.; Ruth, A.A. Erratum: Incoherent broad-band cavity-enhanced absorption spectroscopy of liquids. Rev. Sci. Instrum. 2003, 76, 023107. [CrossRef]

18. Fiedler, S.E.; Hese, A.; Heitmann, U. Influence of the cavity parameters on the output intensity in incoherent broadband cavity-enhanced absorption spectroscopy. Rev. Sci. Instrum. 2007, 78, 073104. [CrossRef] [PubMed]

19. Zhao, W.X.; Xu, X.Z.; Fang, B.; Zhang, Q.L.; Qian, X.D.; Wang, S.; Liu, P.; Zhang, W.J.; Wang, Z.Z.; Liu, D.; et al. Development of an incoherent broad-band cavity-enhanced aerosol extinction spectrometer and its application to measurement of aerosol optical hygroscopicity. Appl. Opt. 2017, 56, E16-E22. [CrossRef] [PubMed]

20. Fang, B.; Zhao, W.X.; Xu, X.Z.; Zhou, J.C.; Ma, X.; Wang, S.; Zhang, W.J.; Venables, D.S.; Chen, W.D. Portable broadband cavity-enhanced spectrometer utilizing Kalman filtering: Application to real-time, in-situ monitoring of glyoxal and nitrogen dioxide. Opt. Express 2017, 25, 26910-26922. [CrossRef] [PubMed]

21. Wilbers, A.T.M.; Kroesen, G.M.W.; Timmermans, C.J.; Schram, D.C. The continuum emission of an arc plasma. J. Quant. Spectrosc. Radiat. Transf. 1991, 45, 1-10. [CrossRef]

22. Ruth, A.A.; Orphal, J.; Fiedler, S.E. Fourier-transform cavity-enhanced absorption spectroscopy using an incoherent broadband light source. Appl. Opt. 2007, 46, 3611-3616. [CrossRef] [PubMed]

23. Orphal, J.; Ruth, A.A. High-resolution Fourier-transform cavity-enhanced absorption spectroscopy in the near-infrared using an incoherent broad-band light source. Opt. Express 2008, 16, 19232-19243. [CrossRef] [PubMed]

24. Fiedler, S.E.; Hoheisel, G.; Ruth, A.A.; Hese, A. Incoherent broad-band cavity-enhanced absorption spectroscopy of azulene in a supersonic jet. Chem. Phys. Lett. 2003, 382, 447-453. [CrossRef]

25. Venables, D.S.; Gherman, T.; Orphal, J.; Wenger, J.C.; Ruth, A.A. High sensitivity in-situ monitoring of $\mathrm{NO}_{3}$ in an atmospheric simulation chamber using incoherent broadband cavity-enhanced absorption spectroscopy. Environ. Sci. Technol. 2006, 40, 6758-6763. [CrossRef] [PubMed] 
26. Vaughan, S.; Gherman, T.; Ruth, A.A.; Orphal, J. Incoherent broad-band cavity-enhanced absorption spectroscopy of the marine boundary layer species $\mathrm{I}_{2}, \mathrm{IO}$ and OIO. Phys. Chem. Chem. Phys. 2008, 10, 4471-4477. [CrossRef] [PubMed]

27. Washenfelder, R.A.; Langford, A.O.; Fuchs, H.; Brown, S.S. Measurement of glyoxal using an incoherent broadband cavity enhanced absorption spectrometer. Atmos. Chem. Phys. 2008, 8, 7779-7793. [CrossRef]

28. Dixneuf, S.; Ruth, A.A.; Vaughan, S.; Varma, R.M. The time dependence of molecular iodine emission from Laminaria digitate. Atmos. Chem. Phys. 2008, 8, 823-829.

29. Nitschke, U.; Ruth, A.A.; Dixneuf, S.; Stengel, D.B. Molecular iodine emission rates and photosynthetic performance of different thallus parts of Laminaria digitata (Phaeophyceae) during emersion. Planta 2011, 233, 737-748. [CrossRef] [PubMed]

30. Chen, J.; Venables, D.S. A broadband optical cavity spectrometer for measuring weak near-ultraviolet absorption spectra of gases. Atmos. Meas. Tech. 2010, 3, 425-436. [CrossRef]

31. Chen, J.; Wenger, J.C.; Venables, D.S. Near-ultraviolet absorption cross sections of nitrophenols and their potential influence on tropospheric oxidation capacity. J. Phys. Chem. A 2011, 115, 12235-12242. [CrossRef] [PubMed]

32. Ashu-Ayem, E.R.; Nitschke, U.; Monahan, C.; Chen, J.; Darby, S.B.; Smith, P.D.; O’Dowd, C.D.; Stengel, D.B.; Venables, D.S. Coastal iodine emissions. 1. Release of $\mathrm{I}_{2}$ by Laminaria digitata in chamber experiments. Environ. Sci. Technol. 2012, 46, 10413-10421. [CrossRef] [PubMed]

33. Cui, X.J.; Lengignon, C.; Wu, T.; Zhao, W.X.; Wysocki, G.; Fertein, E.; Coeur, C.; Cassez, A.; Croize, L.; Chen, W.D.; et al. Photonic sensing of the atmosphere by absorption spectroscopy. J. Quant. Spectrosc. Radiat. Transf. 2012, 113, 1300-1316. [CrossRef]

34. Ball, S.M.; Langridge, J.M; Jones, R.L. Broadband cavity enhanced absorption spectroscopy using light emitting diodes. Chem. Phys. Lett. 2004, 398, 68-74. [CrossRef]

35. Denzer, W.; Hamilton, M.L.; Hancock, G.; Islam, M.; Langley, C.E.; Peverall, R.; Ritchie, G.A.D. Near-infrared broad-band cavity enhanced absorption spectroscopy using a superluminescent light emitting diode. Analyst 2009, 134, 2220-2223. [CrossRef] [PubMed]

36. Denzer, W.; Hancock, G.; Islam, M.; Langley, C.E.; Peverall, R.; Ritchie, G.A.D.; Taylor, D. Trace species detection in the near infrared using Fourier transform broadband cavity enhanced absorption spectroscopy: Initial studies on potential breath analytes. Analyst 2011, 136, 801-806. [CrossRef] [PubMed]

37. Udem, T.; Holzwarth, R.; Hänsch, T.W. Optical frequency metrology. Encyclopedia Mater. Sci. Technol. 2005, 416, 233-237.

38. Kasparian, J.; Rodriguez, M.; Méjean, G.; Yu, J.; Salmon, E.; Wille, H.; Bourayou, R.; Frey, S.; Andre, Y.B.; Mysyrowicz, A.; et al. White-light filaments for atmospheric analysis. Science 2003, 301, 61-64. [CrossRef] [PubMed]

39. Sfeir, M.Y.; Wang, F.; Huang, L.; Chuang, C.C.; Hone, J.; O’brien, S.P.; Heinz, T.F.; Brus, L.E. Probing electronic transitions in individual carbon nanotubes by Rayleigh scattering. Science 2004, 306, 1540-1543. [CrossRef] [PubMed]

40. Unterhuber, A.; Povazay, B.; Bizheva, K.; Hermann, B.; Sattmann, H.; Stingl, A.; Le, T.; Seefeld, M.; Menzel, R.; Preusser, M. Advances in broad bandwidth light sources for ultrahigh resolution optical coherence tomography. Phys. Med. Biol. 2004, 49, 1235-1246. [CrossRef] [PubMed]

41. Jia, S.J.; Yao, C.F.; Zhao, Z.P.; Jia, Z.X.; Qin, G.S.; Ohishi, Y.; Qin, W.P. Flat supercontinuum generation from 1028-2804 $\mathrm{nm}$ in an all-solid fluorotellurite fiber. Laser Phys. Lett. 2018, 15, 115104-115108. [CrossRef]

42. Langridge, J.M.; Laurila, T.; Watt, R.S.; Jones, R.L.; Kaminski, C.F.; Hult, J. Cavity enhanced absorption spectroscopy of multiple trace gas species using a supercontinuum radiation source. Opt. Express 2008, 16, 10178-10188. [CrossRef] [PubMed]

43. Ruth, A.A.; Dixneuf, S.; Orphal, J. Laser-induced plasmas in ambient air for incoherent broadband cavity-enhanced absorption spectroscopy. Opt. Express 2015, 23, 6092-6101. [CrossRef] [PubMed]

44. Wang, H.C.; Chen, J.; Lu, K.D. Development of a portable cavity-enhanced absorption spectrometer for the measurement of ambient $\mathrm{NO}_{3}$ and $\mathrm{N}_{2} \mathrm{O}_{5}$ : Experimental set-up, lab characterizations, and field applications in a polluted urban environment. Atmos. Meas. Tech. 2017, 10, 1465-1479. [CrossRef]

45. Ling, L.Y.; Xie, P.H.; Lin, P.P.; Huang, Y.R.; Qin, M.; Duan, J.; Hu, R.Z.; Wu, F.C. A concentration retrieval method for incoherent broadband cavity-enhanced absorption spectroscopy based on $\mathrm{O}_{2}-\mathrm{O}_{2}$ absorption. Acta Phys. Sin. 2015, 64, 82-88. 
46. Fuchs, H.; Ball, S.M.; Bohn, B.; Brauers, T.; Cohen, R.C.; Dorn, H.P.; Dube, W.P.; Fry, J.L.; Haseler, R.; Heitmann, U.; et al. Intercomparison of measurements of $\mathrm{NO}_{2}$ concentrations in the atmosphere simulation chamber SAPHIR during the $\mathrm{NO}_{3}$ Comp campaign. Atmos. Meas. Tech. 2009, 2, 21-37.

47. Wu, T.; Chen, W.; Fertein, E.; Cazier, F.; Dewaele, D.; Gao, X. Development of an open-path incoherent broadband cavity-enhanced spectroscopy based instrument for simultaneous measurement of HONO and $\mathrm{NO}_{2}$, in ambient air. Appl. Phys. B 2012, 106, 501-509. [CrossRef]

48. Ruth, A.A.; Dixneuf, S.; Raghunandan, R. Broadband Cavity-Enhanced Absorption Spectroscopy with Incoherent Light. In Cavity-Enhanced Spectroscopy and Sensing; Gagliardi, G., Loock, H.P., Eds.; Springer: Berlin/Heidelberg, Germany, 2014; Volume 179.

49. Fiddler, M.N.; Begashaw, I.; Mickens, M.A.; Collingwood, M.S.; Assefa, Z.; Bililign, S. Laser spectroscopy for atmospheric and environmental sensing. Sensors 2009, 9, 10447-10512. [CrossRef] [PubMed]

50. Ventrillard-Courtillot, I.; O’Brien, E.S.; Kassi, S.; Méjean, G.; Romanini, D. Incoherent broad-band cavity-enhanced absorption spectroscopy for simultaneous trace measurements of $\mathrm{NO}_{2}$, and $\mathrm{NO}_{3}$ with a LED source. Appl. Phys. B 2010, 101, 661-669. [CrossRef]

51. Wu, T.; Coeur-Tourneurb, C.; Dhont, G.; Cassez, A.; Fertein, E.; He, X.D.; Chen, W.D. Simultaneous monitoring of temporal profiles of $\mathrm{NO}_{3}, \mathrm{NO}_{2}$, and $\mathrm{O}_{3}$, by incoherent broadband cavity enhanced absorption spectroscopy for atmospheric applications. J. Quant. Spectrosc. Radiat. Transf. 2014, 133, 199-205. [CrossRef]

52. Kennedy, O.J.; Ouyang, B.; Langridge, J.M.; Daniels, M.J.S.; Bauguitte, S.; Freshwater, R.; McLeod, M.W.; Ironmonger, C.; Sendall, J.; Norris, O.; et al. An aircraft based three channel broadband cavity enhanced absorption spectrometer for simultaneous measurements of $\mathrm{NO}_{3}, \mathrm{~N}_{2} \mathrm{O}_{5}$ and $\mathrm{NO}_{2}$. Atmos. Meas. Tech. 2011, 4, 1759-1776. [CrossRef]

53. Gherman, T.; Venables, D.S.; Vaughan, S.; Orphal, J.; Ruth, A.A. Incoherent broadband cavity-enhanced absorption spectroscopy in the near-ultraviolet: Application to $\mathrm{HONO}$ and $\mathrm{NO}_{2}$. Environ. Sci. Technol. 2008, 42, 890-895. [CrossRef] [PubMed]

54. Wu, T.; Zha, Q.Z.; Chen, W.D.; Zheng, X.; Wang, T.; He, X.D. Development and deployment of a cavity enhanced UV-LED spectrometer for measurements of atmospheric $\mathrm{HONO}$ and $\mathrm{NO}_{2}$, in Hong Kong. Atmos. Environ. 2014, 95, 544-551. [CrossRef]

55. Duan, J.; Qin, M.; Fang, W.; Ling, L.Y.; Hu, R.Z.; Lu, X.; Shen, L.L.; Wang, D.; Xie, P.H.; Liu, J.G.; et al. Incoherent broadband cavity enhanced absorption spectroscopy for measurements of atmospheric HONO. Acta Phys. Sin. 2015, 64, 222-229.

56. Langridge, J.M.; Ball, S.M.; Shillings, A.J.L.; Jones, R.L. A broadband absorption spectrometer using light emitting diodes for ultrasensitive, in-situ trace gas detection. Rev. Sci. Instrum. 2008, 79, 123110. [CrossRef] [PubMed]

57. Triki, M.; Cermak, P.; Méjean, G.; Romanini, D. Cavity-enhanced absorption spectroscopy with a red LED source for NOx, trace analysis. Appl. Phys. B 2008, 91, 195-201. [CrossRef]

58. Langridge, J.M.; Ball, S.M.; Jones, R.L. A compact broadband cavity enhanced absorption spectrometer for detection of atmospheric $\mathrm{NO}_{2}$ using light emitting diodes. Analyst 2006, 131, 916-922. [CrossRef] [PubMed]

59. Wu, T.; Zhao, W.X.; Li, J.S.; Zhang, W.J.; Chen, W.D.; Gao, X.M. Incoherent broadband cavity enhanced absorption spectroscopy based on LED. Spectrosc. Spect. Anal. 2008, 28, 2469-2472.

60. Wu, T.; Zhao, W.X.; Chen, W.D.; Zhang, W.J.; Gao, X.M. Incoherent broadband cavity enhanced absorption spectroscopy for in-situ measurements of $\mathrm{NO}_{2}$ with a blue light emitting diode. Appl. Phys. B 2009, 94, 85-94. [CrossRef]

61. Ling, L.Y.; Xie, P.H.; Qin, M.; Fang, W.; Jiang, Y.; Hu, R.Z.; Zheng, N.N. In-situ measurements of atmospheric $\mathrm{NO}_{2}$ using incoherent broadband cavity-enhanced absorption spectroscopy with a blue light-emitting diode. Chin. Opt. Lett. 2013, 11, 77-80. [CrossRef]

62. Liang, S.X.; Qin, M.; Duan, J.; Fang, W.; Li, A.; Xu, J.; Lu, X.; Tang, K.; Xie, P.H.; Liu, J.G.; et al. Airborne cavity enhanced absorption spectroscopy for high time resolution measurements of atmospheric $\mathrm{NO}_{2}$. Acta Phys. Sin. 2017, 66, 74-81.

63. Nakashima, Y.; Sadanaga, Y. Validation of in-situ Measurements of Atmospheric Nitrous Acid Using Incoherent Broadband Cavity-enhanced Absorption Spectroscopy. Anal. Sci. 2017, 33, 519-524. [CrossRef] [PubMed]

64. Johansson, O.; Mutelle, H.; Parker, A.E.; Batut, S.; Demaux, P.; Schoemaecker, C.; Fittschen, C. Quantitative IBBCEAS measurements of $\mathrm{I}_{2}$ in the presence of aerosols. Appl. Phys. B 2014, 114, 421-432. [CrossRef] 
65. Chandran, S.; Varma, R. Near infrared cavity enhanced absorption spectra of atmospherically relevant ether-1, 4-Dioxane. Spectrochim. Acta A 2015, 153, 704-708. [CrossRef] [PubMed]

66. Ruth, A.A. Hochauflösende optische Absorptionsspektroskopie: Cavity-Ring-Down-Spektroskopie. Physikalische Blätter 2015, 55, 47-49. [CrossRef]

67. Yi, H.M.; Wu, T.; Wang, G.S.; Zhao, W.X.; Fertein, E.; Coeur, C.; Gao, X.X.; Zhang, W.J.; Chen, W.D. Sensing atmospheric reactive species using light emitting diode by incoherent broadband cavity enhanced absorption spectroscopy. Opt. Express 2016, 24, A781-A790. [CrossRef] [PubMed]

68. Zheng, K.Y.; Zheng, C.T.; He, Q.X.; Yao, D.; Hu, L.E.; Zhang, Y.; Wang, Y.D.; Tittel, F.K. Near-infrared acetylene sensor system using off-axis integrated-cavity output spectroscopy and two measurement schemes. Opt. Express 2018, 26, 26205-26216. [CrossRef]

69. Monks, P.S. Gas-phase radical chemistry in the troposphere. Chem. Soc. Rev. 2005, 34, 376-395. [CrossRef] [PubMed]

70. Zheng, K.Y.; Zheng, C.T.; Liu, Z.D.; He, Q.X.; Du, Q.L.; Zhang, Y.; Wang, Y.D.; Tittel, F.K. Near-infrared broadband cavity-enhanced sensor system for methane detection using a wavelet-denoising assisted Fourier-transform spectrometer. Analyst 2018, 143, 4699-4706. [CrossRef] [PubMed]

71. Zheng, C.T.; Ye, W.L.; Sanchez, N.P.; Li, C.G.; Dong, L.; Wang, Y.D.; Griffin, R.J.; Tittel, F.K. Development and field deployment of a mid-infrared methane sensor without pressure control using interband cascade laser absorption spectroscopy. Sens. Actuators B Chem. 2017, 244, 365-372. [CrossRef]

72. Huisman, A.J.; Hottle, J.R.; Galloway, M.M.; DiGangi, J.P.; Coens, K.L.; Choi, W.; Faloona, I.C.; Gilman, J.B.; Kuster, W.C.; de Gouw, J.; et al. Photochemical modeling of glyoxal at a rural site: Observations and analysis from BEARPEX 2007. Atmos. Chem. Phys. 2011, 11, 8883-8897. [CrossRef]

73. Fu, T.M.; Jacob, D.J.; Wittrock, F.; Burrows, J.P.; Vrekoussis, M.; Henze, D.K. Global budgets of atmospheric glyoxal and methylglyoxal, and implications for formation of secondary organic aerosols. J. Geophys. Res. Atmos. 2008, 113, D15. [CrossRef]

74. Volkamer, R.; Martini, F.S.; Molina, L.T.; Salcedo, D.; Jimenez, J.L.; Molina, M.J. A missing sink for gas-phase glyoxal in Mexico City: Formation of secondary organic aerosol. Geophys. Res. Lett. 2007, 34, 255-268. [CrossRef]

75. Chameides, W.L.; Davis, D.D. Iodine: Its possible role in tropospheric photochemistry. J. Geophys. Res. Oceans 1980, 85, 7383-7398. [CrossRef]

76. Vogt, R.; Sander, R.; Glasow, R.V.; Crutzen, P.J. Iodine chemistry and its role in halogen activation and ozone loss in the marine boundary layer: A model study. J. Atmos. Chem. 1999, 32, 375-395. [CrossRef]

77. Allan, B.J.; McFiggans, G.; Plane, J.M.C.; Coe, H. Observations of iodine monoxide in the remote marine boundary layer. J. Geophys. Res. 2000, 105, 14363-14369. [CrossRef]

78. Carpenter, L.J. Iodine in the marine boundary layer. Chem. Rev. 2003, 103, 4953. [CrossRef] [PubMed]

79. Saiz-Lopez, A.; Plane, J.M.C. Recent applications of differential optical absorption spectroscopy: Halogen chemistry in the lower troposphere. J. Phys. IV 2004, 121, 223-238. [CrossRef]

80. Mcfiggans, G.; Plane, J.M.C.; Allan, B.J.; Carpenter, L.J.; Coe, H.; O’Dowd, C. A modeling study of iodine chemistry in the marine boundary layer. J. Geophys. Res. Atmos. 2000, 105, 14371-14385. [CrossRef]

81. O’Dowd, C.D.; Jimenez, J.L.; Bahreini, R.; Flagan, R.C.; Seinfeld, J.H.; Hämeri, K.; Pirjola, L.; Kulmala, M.; Jennings, S.G.; Hoffmann, T. Marine aerosol formation from biogenic iodine emissions. Nature 2002, 417, 632-636. [CrossRef] [PubMed]

82. O’Dowd, C.D.; Yoon, Y.J.; Junkerman, W.; Aalto, P.; Kulmala, M.; Lihavainen, H.; Viisanen, Y. Airborne measurements of nucleation mode particles I: Coastal nucleation and growth rates. Atmos. Chem. Phys. 2007, 7, 1491-1501. [CrossRef]

83. Pirjola, L.; O’Dowd, C.D.; Yoon, Y.J.; Sellegri, K. Modelling iodine particle formation and growth from seaweed in a chamber. Environ. Chem. 2006, 2, 271-281. [CrossRef]

84. Saiz-Lopez, A.; Plane, J.M.C.; Mcfiggans, G.; Williams, P.I.; Ball, S.M.; Bitter, M.; Jones, R.L.; Hongwei, C.; Hoffmann, T. Modelling molecular iodine emissions in a coastal marine environment: The link to new particle formation. Atmos. Chem. Phys. 2006, 6, 883-895. [CrossRef]

85. Saunders, R.W.; Kumar, R.; Gómez Martín, J.C.; Mahajan, A.S.; Murray, B.J.; Plane, J.M.C. Studies of the formation and growth of aerosol from molecular iodine precursor. Int. J. Res. Phys. Chem. Chem. Phys. 2010, 224, 1095-1117. [CrossRef] 
86. Sellegri, K.; Yoon, Y.J.; Jennings, S.G.; O’Dowd, C.D.; Pirjola, L.; Cautenet, S.; Chen, H.W.; Hoffmann, T. Quantification of coastal new ultra-fine particles formation from in-situ and chamber measurements during the BIOFLUX campaign. Environ. Chem. 2006, 2, 260-270. [CrossRef]

87. Reeser, D.I.; Kwamena, N.O.A.; Donaldson, D.J. Effect of organic coatings on gas-phase Nitrogen dioxide production from aqueous nitrate photolysis. J. Phys. Chem. C 2013, 117, 22260-22267. [CrossRef]

88. Alfonso, S.; Plane, J.M.C. Novel iodine chemistry in the marine boundary layer. Geophys. Res. Lett. 2004, 31, 235-250.

89. Shirey, R.E.; Linton, C.M. The extraction and analysis of 1,4-dioxane from water using solid-phase microextraction coupled with gas chromatography and gas chromatography-mass spectrometry. J. Chromatogr. Sci. 2006, 44, 444-450. [CrossRef] [PubMed]

90. Nishimura, T.; Iizuka, S.; Kibune, N.; Ando, M.; Magara, Y. Study of 1,4-Dioxane Intake in the Total Diet. J. Health Sci. 2004, 51, 514-517. [CrossRef]

91. Aalto, A.; Genty, G.; Laurila, T.; Toivonen, J. Incoherent broadband cavity enhanced absorption spectroscopy using supercontinuum and superluminescent diode sources. Opt. Express 2015, 23, 25225-25234. [CrossRef] [PubMed]

92. Amiot, C.; Aalto, A.; Ryczkowski, P.; Toivonen, J.; Genty, G. Cavity enhanced absorption spectroscopy in the mid-infrared using a supercontinuum source. Appl. Phys. Lett. 2017, 111, 061103. [CrossRef]

93. Watt, R.S.; Laurila, T.; Kaminski, C.F.; Hult, J. Cavity enhanced spectroscopy of high-temperature $\mathrm{H}_{2} \mathrm{O}$ in the near-infrared using a supercontinuum light source. Appl. Spectrosc. 2009, 63, 1389-1395. [CrossRef] [PubMed]

94. Nakashima, Y.; Sadanaga, Y.; Saito, S.; Hoshi, J.; Ueno, H. Contributions of vehicular emissions and secondary formation to nitrous acid concentrations in ambient urban air in Tokyo in the winter. Sci. Total Environ. 2017, 592, 178-186. [CrossRef] [PubMed]

95. Räikkönen, E.; Kaivola, M.; Buchter, S. Compact supercontinuum source for the visible using gain-switched Ti: Sapphire laser as pump. J. Eur. Opt. Soc. Rapid 2006, 1, 06012-06015. [CrossRef]

96. Reeves, W.H.; Skryabin, D.V.; Biancalana, F.; Knight, J.C.; Russell, P.S.J.; Omenetto, F.G.; Efimov, A.; Taylor, A.J. Transformation and control of ultra-short pulses in dispersion-engineered photonic crystal fibres. Nature 2003, 424, 511-515. [CrossRef] [PubMed]

97. Johnston, P.S.; Lehmann, K.K. Cavity enhanced absorption spectroscopy using a broadband prism cavity and a supercontinuum source. Opt. Express 2008, 16, 15013-15023. [CrossRef] [PubMed]

98. Lee, B.; Lehmann, K.; Taylor, J.; Yalin, A. A high-finesse broadband optical cavity using calcium fluoride prism retroreflectors. Opt. Express 2014, 22, 11583-11591. [CrossRef] [PubMed]

99. Kudlinski, A.; George, A.K.; Knight, J.C.; Travers, J.C.; Rulkov, A.B.; Popov, S.V.; Taylor, J.R. Zero-dispersion wavelength decreasing photonic crystal fibers for ultraviolet-extended supercontinuum generation. Opt. Express 2006, 14, 5715-5722. [CrossRef] [PubMed]

100. Xia, C.A.; Kumar, M.; Cheng, M.Y.; Hegde, R.S.; Islam, M.N.; Galvanauskas, A.; Winful, H.G.; Terry, F.L.; Freeman, M.J.; Poulain, M.; et al. Power scalable mid-infrared supercontinuum generation in ZBLAN fluoride fibers with up to 1.3 watts time-averaged power. Opt. Express 2007, 15, 865-871. [CrossRef] [PubMed]

101. Kilgus, J.; Duswald, K.; Langer, G.; Brandstetter, M. Mid-Infrared Standoff Spectroscopy Using a Supercontinuum Laser with Compact Fabry-Pérot Filter Spectrometers. Appl. Spectrosc. 2018, 72, 634-642. [CrossRef] [PubMed]

(C) 2018 by the authors. Licensee MDPI, Basel, Switzerland. This article is an open access article distributed under the terms and conditions of the Creative Commons Attribution (CC BY) license (http://creativecommons.org/licenses/by/4.0/). 